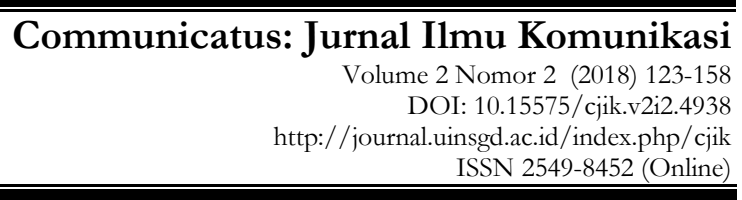

\title{
Komunikasi Terapeutik Perawat Rohani Islam dalam Proses Penyembuhan Pasien di RSUD Ciamis
}

\author{
Ibin Hasani \\ Rumah Sakit Umum Daerah, Ciamis \\ ibinhasani71@gmail.com
}

ABSTRACT

In general, the purpose of research is to find, know, explain, assess, compare, develop and prove knowledge. Specifically the purpose of this research are: 1) To find out therapeutic communication carried out by Islamic Spiritual Nurses (Warois) in the process of healing inpatients in Ciamis Hospital.2) To find out Warois therapeutic communication methods and techniques. 3) To find out the contents of Warois's therapeutic communication message in the process of healing inpatients in Ciamis Hospital. 4) To find out the results of Therois therapeutic communication in helping the healing process of inpatients in Ciamis Hospital. This study used a phenomenological method with a qualitative approach. The success of therapeutic communication of Islamic spiritual care officers can be seen from the positive response from patients and families, namely the existence and occurrence of behavioral changes in patients and families. When the patient had not been given guidance and counseling by officer $W$ arois, the patient felt very severe pain, so he was screaming very loudly, after guidance and counseling, he did not scream again despite experiencing severe pain, but he instead glorified and converted, to Allah SWT.

Keywords: keyword: therapeutic communication, warois, patien

\begin{abstract}
ABSTRAK
Secara umum tujuan dari penelitian adalah untuk menemukan, mengetahui, menjelaskan, menilai, membandingkan, mengembangkan dan membuktikan pengetahuan. Secara khusus tujuan penelitian ini adalah:1) Untuk mengetahui komunikasi terapeutik yang dilakukan oleh Perawat Rohani Islam (Warois) dalam proses penyembuhan pasien rawat inap di RSUD Ciamis.2) Untuk mengetahui metode dan teknik komunikasi terapeutik Warois. 3) Untuk mengetahui isi pesan komunikasi terapeutik Warois dalam proses penyembuhan pasien rawat inap di RSUD Ciamis. 4) Untuk mengetahui hasil dari komunikasi terapeutik Warois dalammembantu proses penyembuhan pasien rawat inap di RSUD Ciamis. Penelitian ini menggunakan metode fenomenologis dengan pendekatan kualitatif. Keberhasilan komunikasi terapeutik petugas perawatan rohani Islam dapat dilihat dari adanya respon yang positif dari pasien dan keluarga, yaitu ada dan terjadinya perubahan prilaku pada diri pasien dan keluarga. Ketika pasien tersebut belum dilakukan bimbingan dan konseling oleh petugas Warois, pasien tersebut karena merasa kesakitan yang amat sangat, sehingga berteriak-teriak sangat keras, setelah dilakukan bimbingan dan konseling, maka ia tidak berteiak-teriak
\end{abstract}


Ibin Hasani

lagi walaupun mengalami rasa sakit yang sangat, tapi ia malah bertasbih dan beristigfafar, kepada Allah SW'T.

Kata kunci : komunikasi terapeutik, warois, pasien

\section{PENDAHULUAN}

Perjalanan hidup manusia tidak selamanya lurus dan mulus sesuai dengan keinginan atau harapan, hal - hal yang tidak diharapkan sering datang dan mucul secara tiba-tiba, itulah liku-liku kehidupan di dunia. Demikian pula kondisi tubuh atau fisik manusia, tidak selamanya berada dalam kondisi fit, sehat danprima, suatu waktu akan mengalami yang namanya sakit. Sehat dan sakit merupakan Sunnatullah.

Ketika tubuh atau fisik manusia mengalami kelelahan, maka daya tahan tubuh akan menurun atau lemah, maka ketika itu tubuh seseorang akan merasa kesehatannya terganggu dan disebut sakit.Sakit adalah menderita sesuatu yang mendatangkan rasa tidak nyaman pada tubuh atau bagian tubuh karena alat-alat pada tubuh atau bagian tubuh terganggu hingga tidak dapat bekerja sebagai mestinya (Poerwadarminta, $2014:$ 1010).

Adapun definisi atau pengertian sakit menurut para ahli, dan lembaga yang berwenang yaitu: (1) Pemons (1972), sakit adalah gangguan dalam fungsi normal individu sebagai totalitas termasuk keadaan organisme sebagai sistem biologis dan penyesuaian sosialnya. (2) Perkins (1939), sakit adalah sebagai suatu keadaan yang tidak menyenangkan yang menimpa seseorang sehingga menimbulkan gangguan aktivitas sehari-hari baik itu dalam aktivitas jasmani, rohani dan sosial. (3) Ibnu Qayyim al-Zawzi dalamal-Tbib an-Nabawi, bahwa secara umum penyakit itu dibagi dua macam, yakni: pertama, penyakit hati atau penyakit jiwa, dan kedua, penyakit badan atau penyakit jasad. Sedangkan yang dimaksud penyakit adalah suatu situasi jasmani dan atau ruhani yang hilang keseimbangan dan keharmonisan interaksi antar unsur - unsur yang ada pada ruhani maupun jasmani (Sambas dan Sukayat, $2002: 199)$.

Selanjutnya Ibnu Qayyim menjelaskan yang dimaksud penyakit ruhani (qalbu) adalah situasi dan kondisi qalbu yang keluar dari kesehatan dan keharmonisannya, dengan ditandai terdapat gerak menyimpang dari garis aktivitas mentauhidkan Allah SWT, dan mencintainya. Sedangkan yang dimaksud dengan penyakit jasad adalah situasi dan kondisi jasmani atau fisik jasadiyah yang hilang keseimbangan dan keharmonisan antara unsur - unsur asal kejadian fisik, yaitu unsur panas dari api, unsur dingin dari air, unsur halus dari hawa, dan unsur ketenangan dari bumi (Sambas dan Sukayat, $2002: 200)$.

WHO (1974) sebagai organisasi kesehatan dunia memberikan batasan atau definisi sakit yaitu, suatu kondisi tidak seimbang atau sempurna seseorang dari aspek medis, fisik, mental, sosial, psikologis, danbukan hanya mengalami kesakitan tapi juga mengalami kecacatan. Sedangkan menurut: UU No. 23 tahun 
Komunikasi Terapeutik Perawat Rohani Islam dalam Proses Penyembuhan Pasien di RSUD Ciamis 1992, seseorang dikatakan sakit apabila iamenderita penyakit menahun (kronis) atau gangguan kesehatan lain yang menyebabkan aktivitas kerja atau kegiatannya terganggu (Murwani, 2008: 150-151).

Setelah memperhatikan pendapat para ahli dan yang dikeluarkan oleh lembaga yang berwenang, maka dapat disimpulkan bahwa sakit merupakan suatu keadaan atau suatu hal yang disebabkan oleh gangguan terhadap sistem tubuh, sehingga tubuh tidak dapat melakukan aktivitasnya, serta berdampak pada terganggunya kesehatan mental (rohaninya). Maka orang sakit adalah orang yang mengalami gangguan kesehatan jasmani maupun rohani, sehingga menyebabkan aktivitas terganggu.

Orang yang menderita sakit fisik dapat dipastikan jiwanya (psikis) dalam keadaan labil, karena mengalami goncangan atau shock, berbagai perasaan menghinggapinya, seperti rasa takut, cemas atau khawatir, menarik diri, egosentris, sensitif dan cenderung emosional, perubahan persepsi dan berkurangnya minat (Arifin, 2015 : 43-45). Hal tersebut dapat dilihat dari perilaku sakit (illnes behavior) yang diekspresikan oleh orang yang menderita sakit, dan itu merupakan gambaran dari kondisi psikologinya. Perilaku yang ditampilkan orang sakit itu berbeda - beda, antara orang yang satu dengan yang lainnya, karena hal tersebut dipengaruhi oleh berbagai hal seperti latar belakang sosial-ekonomi, psikologi dan budaya (etnik) (Siregar, 2002 :81). Hal demikian harus difahami oleh orang-orang terkait disekitarnya terutama oleh para perawat atau keluarga si sakit. Di antara perilaku psikologis yang penting difahami adalah perilaku psikologis yang berkaitan dengan kondisi spiritualnya, tahapan sikap, dan dampak dari sakit (Arifin, 2015 : 43).

Spiritualitas mempunyai pengaruh terhadap semua sisi kehidupan manusia, salah satunya adalah terhadap kesehatan fisik/tubuh seseorang. Ketika seseorang ditimpa musibah sakit, sementara kualitas spiritualnya lemah maka ia sulit untuk bisa menerima musibah tersebut. Apabila sakitnya lamaakan mudah putus asa, karena ia mengalami defisit spiritual hingga distress spiritrual. Menurut S. Hamid (2000: 56), Spiritual adalah kondisi ketidakseimbangan yang diakibatkan kekurangan asupan spiritual, ditandai dengan kemunculan pernyataan-pernyataan negatif, seperti putus asa, tidak berdaya, tidak peduli, apatis, pernyataan kesepiandan lain-lain, kondisi yang menggambarkan kehampaan dan kekosongan spiritual(Arifin, 2015 : 20).

Sedangkan distress spiritual adalah hambatan kemampuan yang dialami seseorang untuk mengintegrasikan makna dan tujuan dalam hidup melalui hubungan dengan diri sendiri, orang lain, musik, seni, buku, alam, ataupun dengan Tuhan Yang Maha Esa, atau gangguan penyesuaian terhadap penyakit yang berhubungan dengan ketidakmampuan untuk merekonsiliasi penyakit dengan keyakinan spiritual. Distress spiritual merupakan suatu keadaan ketika individu atau kelompok mengalami atau beresiko mengalami gangguan dalam kepercayaan atau sistem nilai yang memberikannya kekuatan, harapan dan arti 
Ibin Hasani

kehidupan, yang ditandai dengan pasien meminta pertolongan spiritual(Hidayat dalam Arifin, 2015 : 20-21).

Untuk peningkatan kualitas dan mutu di sektor jasa layanan kesehatan, pemerintah melalui kementerian kesehatan membentuk KomisiAkreditasi Rumah Sakit (KARS). Komisi tersebut bertugas untuk melakukan akreditasi seluruh rumah sakit dan Puskesmas yang ada di Indonesia baik itu milik pemerintah atau milik swasta. Dengan adanya Akreditasi Rumah Sakit yang dilakukan oleh Komisi Akreditasi Rumah Sakit (KARS), maka rumah sakit rumah sakit saat ini menerapkan standar pelayanan sesuai dengan yang dikeluarkan oleh WHO tahun 1984, yaitu bio - psiko - sosio - spiritual. Dengan demikian pemenuhan layanan spiritual di semua rumah sakit yang sudah terakreditasi mestinya harus ada, karena merupakan salah satu bagian atau elemen pada kelompok kerja Hak Pasein dan Keluaraga (Pokja HPK).

Rumah Sakit Umum Daerah (RSUD) Ciamis sebagai rumah sakit yang sudah terakreditasi oleh KARS, telah menerapkan standar layanan yang ditetapkan WHO tahun 1984. Untuk pemenuhan layanan spiritual atau kerohanian di RSUD Ciamis, dilakukan oleh Petugas Perawatan Rohani Islam(Warois).Warois adalah kepanjangan dari Perawatan Rohani Islam, yaitu proses pemberian bantuan, pemeliharaan, pengembangan dan pengobatan ruhani dari segala macam gangguan dan penyakit yang mengotori kesucian fitrah ruhani manusia, agar selamat sejahtera dunia dan akhirat (Zaenal Arifin, 2015 : 01). Warois di Rumah Sakit secara depinitif dimaksudkan sebagai proses pemeliharaan, pengurusan, dan penjagaan aktivitas ruhaniah insaniah agar tetap berada dalam situasi dan kondisi yang fitri, yaitu berkeyakinan taubidullah, sabar, tawakal, tumaninah, dan berikhtiar dalam mengatasi dan menjalani musibah penyakit, dan selalu bersyukur dalam menjalani anugrah nikmat kesehatan rohani dan jasmani yang dilakukan oleh diri sendiri atau melalui perbantuan orang lain dengan cara menjalankan kewajiban beragama Islam dalam berbagai situasi dan kondisi(Pemprov Jabar, 2002:4).

Secara historis keberadaan petugas Warois di rumah sakit, diawali oleh suatu peristiwa atau keadaan pada tahun 2002, dimana terjadi trend menarik, yakni meningkatnya perhatian di kalangan masyarakat luas tentang pentingnya menjaga kesehatan, termasuk di dalamnya penyembuhan dari pelbagai penyakit, melalui kesadaran akan pentingnya nilai-nilai reliugiusitas. Di toko - toko buku terpampang buku -buku katagori best seller (terlaris), hampir dipastikan bukubuku tersebut bertema tentang penyembuhan (bealling) yang menekannkan pentingnya pendekatan spiritualitas dalam proses penyembuhan penyakit. Hal ini menandai munculnya fenomena integrasi antara dua paradigma yang sebelumnya berjalan sendiri-sendiri, yakni paradigma psiko religi Islam yang selama ini milik para ahli hikmah atau tabib dan paradigma medis, milik para dokter modern dan Rumah Sakit. 
Komunikasi Terapeutik Perawat Rohani Islam dalam Proses Penyembuhan Pasien di RSUD Ciamis

Diakui para ahli, bahwa kesehatan masyarakat sangat berkait erat dengan nilai-nilai religiusitas. Sebagaimana yang dikatakan oleh Zakiah Daradjat (2002), bahwa banyak yang memilki penyakit dan penderitaan yang bersifat mental disebabkan karena merasa telah melangggar ajaran agama, atau merasa gelisah karena keyakinannya goncang (Daradjat, 2002 :7). Di Rumah Sakit milik pemerintah, bisa dikatakan terlambat menyediakan layanan bimbingan keruhanian terhadap mereka yang ditimpa musibah penyakit. Di rumah sakit rumah sakit milik yayasan organisasi keagamaan, selalu tersedia jasa pembimbing ruhani yang siap memandu setiap pasien ( dengan tidak memperhatikan agama apa yang di anut si pasien) untuk dibimbing dan dituntun (di-talqin) sesuai dengan keyakinan mereka. Ini sesungguhnya ' kekhilafan' dan sekaligus merupakan wilayah garapan dakwah bi absani qawl (penyampaian pesan dakwah melalui bahasa lisan)dan bi ahsani amal (penyampaian pesan dakwah melalui bahasa perbuatan) sangat strategis yang menjadi kewajiban kalangan Muslim untuk melakukannya. Sebab salah satu fungsi al-Qur'an sebagai sumber utama ajaran Islam adalah syifa ( penyembuh bagi penyakit -penyakit).

Mayoritas penduduk Propinsi Jawa Barat adalah Muslim. Hanya 0,5 \% saja yang non Muslim. Dengan demikian, pasien - pasien di Rumah Sakit Umum Daerah sudah dapat dipastikan kebanyakan adalah Muslim pula. Sementara pelayanan bimbingan Islam dalam bentuk perawatan rohani Islam belum dilakukan secara profesional oleh pembimbing atau perawat rohani Islam yang profesional. Padahal kewajiban beragama bagi yang sakit tetap berlaku, dengan ketentuan - ketentuan khusus, seperti kewajiban shalat, berdo'a, sabar, tawakal dan pelafalan kalimah tauhid ketika sakaratul maot. Berangkat dari masalah empirik dakwah yang memperihatinkan itulah, Gubernur Jawa Barat HR. Nuriana memberikan arahan dan petunjuk tentang keharusan adanya upaya dalam mengatasi masalah empirik dakwah tersebut pada saat pertemuanpertemuan dengan Dekan Fakultas Dakwah IAIN SGD, Drs. KH. Syukriadi Sambas M.Si. pada tanggal 23 Maret 2002.

Pokok - pokok arahan dan petunjuk tersebut adalah dipandang perlu (bahkan mendesak) untuk menyiapkan tenaga-tenaga profesional yang akan bertugas sebagai pembimbing atau perawat kerohanian (mursyid) melalui program pelatihan khusus dan terpadu (integrated). Nantinya mereka diharapkan akan menjadi pembimbing shalat, nasihat, do'a-do'a penyembuhan bagai orang yang sedang menderita sakit dan penuntun pelafalan talqin bagi orang-orang yang sedang naza' (sakaratul maut). Pada hakekatnya kegiatan bimbingan tersebut, merupakan bagian dari bentuk dakwah Islam nafsiyah, fardhiyah, dan fi'ah yang diwajibkan bagi setiap individu Muslimmenurut kemampuan, fungsi dan perannya masing-masing.

Untuk pertama kalinya Perawatan Rohani Islam dilaksanakan di Rumah Sakit Umum Daerah Kabupaten Cianjur dan Kabupaten Sumedang, kemudian menyusul daerah Kabupaten/Kota lain di Wilayah Propinsi Jawa Barat. 
Pelaksanaan kegiatan Perawatan Rohani Islam di Rumah Sakit Umum Daerah merupakan program aksi pembangunan terpadu bidang kesehatan dan bidang keagamaan Pemerintah Propinsi Jawa Barat, yang ditangani oleh tim penyelenggara pembinaan dan pengembanganWarois, melalui SK Gubernur No. 451.05/Kep.755-Yansos/2002, tentang Tim Pembina Pelaksanaan Kegiatan Perawatan Rohani Islam (Pemda Propinsi Jabar, 2002 : 5).

Nilai penting Warois adalah bahwa setiap pasien Muslim yang dirawat di RSUD harus selalu terjaga dan terpelihara kewajiban keberagamaannya, meskipun dalam keadaan sakit, karena kewajiban beragama bagi seorang Muslim seperti ibadah shalat tidak bisa ditinggalkan meskipun sakit, kecuali apa bila kondisi kesadaran atau akal sehatnya terganggu seperti somnolen dan koma, maka kewajiaban keberagamaanya seperti shalat ikut hilang. Adapun dalam pelaksanaannya disesuaikan dengan kondisi dan kemampuan pasien atau lebih tepatnya memakai (fiqh li al-maridh), karena yang sakitnya ituadalah fisik, sementara rohaninya sehat, seperti tidak lupa atau daya ingat masih normal, dapat berfikir sehat seperti mampu berdo'a dengan benar, dapat berkomunikasi dengan baik bersama petugas dan keluarga yang menemaninya.

Tidak semua orang yang sakit fisik itu disebabkan oleh bakteri atau virus, karena tidak sedikit orang sakit fisik diakibatkan oleh immateri, seperti kebiasaan atau perilaku yang tidak baik, dan itu dapat menimbulkan penyakit fisik, seperti gangguan pikiran, sakit hati dapat menyebabkan sakit fisik. Selanjutnya tidak semua pasien yang sakit dapat disembuhkan dengan obat farmasi (kimia), karena tidak sedikit penyakit fisik atau gangguan anggota tubuh disebabkan oleh gangguan psikisseperti sakit maag, hipertensi, jantung, dan yang lainnya, maka proses penyembuhannya harus melalui terapi obat farmasi dan terapi spiritual.

Manusia pada hakekatnya adalah makhluk spiritual, maka tidaklah aneh kalau manusia memilki suatu kebutuhan yang tak bisa tergantikan oleh apapun yaitu kebutuhan spiritual. Sepiritual memiliki pengaruh yang signifikan terhadap semua sisi kehidupan manusia. Asuhan spiritual dalam perawatan pasien di rumah sakit merupakan bagian integral yang signifikan. Artinya asuhan spiritual harus selalu ada menyertainya, karena memiliki pengaruh signifikan bagi proses penyembuhan, asuhan spiritual sangat membantu dalam memberikan ketenangan bagi psikologi atau kejiwaan pasien.

Di situ akan nampak pentingnya Warois, karena asuhan spiritual saat ini tidak bisa dilakukan oleh perawat primer karena ada beberapa faktor yang harus dipenuhi yaitu: petugas Perawatan Rohani Islam harus mampu membimbing pasien dalam melakukan ibadah mahdoh, maka petugas Warois harus memilki wawasan yang luas dalam pemahaman keagamaan, di samping benar-benar memahami ilmu agama.

Dokter, perawat, dan Warois merupakan petugas layanan yang selalu berhungan atau bersentuhan langsung dengan pasien dan keluaraga, atau bisa 

disebut ujung tombaknya pelayanan. Untuk menghindari terjadinya kesalah pahaman atau (missunderstanding), maka diperlukan komunikasi khusus yang efektif. Adapun komunikasi khusus itu di kalangan petugas kesehatan disebut komunikasi terapeutik. Komunikasi tersebut merupakan critical skill perawat dan petugas kesehatan lainya.

Komunikasi terapeutik memiliki peranan yang begitu penting dalam membantu proses kesembuhan pasien. Penggunaan komunikasi terapeutik secara benar dapat memberikan jiwa pasien tenang, karena perilaku atau bahasa tubuh (non verbal) yang ditampilkan petugas kesehatan seirama dengan ucapannya, dan itu akan membuat psikologi pasien merasa diperhatikan secara penuh, sehingga memunculkan motivasi yang tinggi pada pasien dalam berusaha untuk sembuh. Komunikasi terapeutik perawat dapat berpengaruh terhadap kepuasan pasien. Hal ini dapat disebabkan karena dalam menerima pelayanan asuhan keperawatan hendaknya juga harus diperhatikan oleh pemberi pelayanan asuhan keperawatan (Kasron, Andhika, \& Kusnaeni, 2013: 106).

Terdapat masalah yang menarik dan unik di RSUD Ciamis, dan ini menjadi alasan dilakukannya penelitian tersebut. Pada umunya komunikasi terapeutik itu dilakukan oleh perawat dan dokter, karena komunikasi terapeutik merupakan critical skill-nya perawat dalam memberikan asuhan keperawatan, saat ini di RSUD Ciamis komunikasi terapeutik dilakukan oleh petugas perawatan rohani Islam (Warois), hal tersebut tentunya akan berbeda dengan perawat primer dalam muatan pesan yang disampaikannya, sehingga dampak atau efek dari pesan yang disampaikannyapun akan berbeda terhadap proses penyembuhan pasien, dengan apa yang dilakukan oleh perawat primer.

Penelitian tentang komunikasi terapeutik dalam proses penyembuhan pasien pernah dilakukan sebelumnya. Di antaranya penelitian Nugroho, Haryanto Adi, Aryati dan Septyani (2012) berjudul "Hubungan antara komunikasi terapeutik perawat dengan kepuasan pasien di Rumah Sakit lslam Kendal" menyimpulkan bahwa komunikasi terapeutik yang dilakukan oleh perawat terhadap pasien memiliki tingkat kepuasan yang tinggi. Sehingga dipandang mampu memberikan pengaruh besar dalam proses kesembuhan pasien.

Penelitian Agustin dan Ike Mardiati (2012) berjudul "Hubungan Pelaksanan Komunikasi Terapeutik dengan Tingkat Kecemasan Pasien Rawat Inap di BP RSUD Kebumen" menyimpulkan bahwa penggunaan komunikasi terapeutik membantu menurunkan kecemasan pasien selama proses perawatan. Oleh karena itu, komunikasi terapeutik memberikan pengaruh positif dalam perkembangan kesembuhan pasien. Penelitian berkaitan dengan hubungan komunikasi terapeutik dalam penanggulangan pecandu narkoba (Yolanda, 2014). Hasil penelitian menunjukkan bahwa komunikasi verbal konselor dalam merespon residen pada saat konseling individu dalam relasi pertolongan yang sudah dijalankan, antara lain; Lead-In Response (respon awal), paraphrasing, 
Reflecting of feeling (merefleksikan perasaan), Open-Ended and ClosedEnded Question (pertanyaan terbuka dan tertutup), Clarification (mengklarifikasi pesan yang disampaikan), Summarization (membuat ikhtisar,) Information Giving (memberikan informasi), Interpretation (interpretasi).

Penelitian Rorie, Priscylia A.C, Pondaag, Hamel dan Rivelano (2014) berjudul "Hubungan Komunikasi Terapeutik Perawat Dengan Kepuasan Pasien Di Ruang Rawat Inap Irina A Rsup Prof. Dr. R. D. Kandou Manado" menyimpulkan bahwa terdapat hubungan signifikan dan linear positif bagaimana pelaksanaan komunikasi terapeutik terhadap pasien rawat inap terbukti mampu membantu proses penyembuhan pasien.

Penelitian Yuwanto, Mahmud Ady, Amrullah dan Akhmad Efrizal (2017) berjudul "Pengaruh Komunikasi Terapeutik Perawat terhadap Kepuasan Pasien di Ruang Rawat Inap Puskesmas Sumbersari" menunjukkan bagaimana pengaruh kuat pelaksanaan komunikasi terapeutik bagi pasien selama proses perawatan dan penyembuhan. Komunikasi terapeutik memberikan kepuasan secara rohani dalam proses penenangan dan pengkondisian pasien selama di rawat. Penelitian berkaitan dengan hubungan komunikasi terapeutik dengan kecemasan pasien (Mulyani, Paramastri, \& Priyanto, 2008). Hasil penelitian menunjukkan bahwa tindakan komunikasi dan hubungan terapeutik perawatklien mampu menurunkan kecemasan prabedah mayor pada aspek fisiologi dan emosional, sementara untuk aspek kognitif tidak menunjukkan perbedaan yang signifikan.

Penelitian lainnya berkaitan dengan Pengaruh Komunikasi Terapeutik Terhadap Kecemasan Lansia Yang Tinggal Di Balai Rehabilitasi Sosial "Mandiri" Pucang Gading Semarang (Azizah, Lestari \& Novitasari, 2013). Hasil penelitian menunjukkan bahwa komunikasi terapeutik dalam penatalaksanaan keperawatan dapat menurunkan derajat kecemasan, terutama pada lansia yang tinggal Balai Rehabilitasi. Penelitian tentang Tingkat Kepuasan Klien Akan Pola Komunikasi Terapeutik Oleh Perawat Di Rumah Sakit Bhayangkara Polda Kalbar (Rahayu, 2013). Penelitian ini menunjukkan bahwa Terdapat hubungan yang kuat antara tingkat kepuasan klien akan komunikasi terapeutik perawat di Rumah Sakit Bhayangkara Polda Kalbar.

Berdasarkan penelitian-penelitian terdahulu didapatkan bahwa bagaimana pentingnya penggunaan komunikasi terapeutik dalam proses penyembuhan pasien. Oleh karena itu, penelitian ini terfokus pada upaya penemuan pola komunikasi terapeutik yang dapat dijadikan model dalam membantu proses penyembuhan pasien di RSUD Ciamis. Penelitian diarahkan untuk menunjukkan bagaimana pentingnya komunikasi terapeutik bagi pasien rawat inap di rumah sakit. Adapun metode penelitian yang digunakan adalah pendekatan kualitatif dengan fenomenologi. Penelitian fenomenologi dapat dimulai dengan memperhatikan dan menelaah fokus fenomena yang hendak diteliti, yang melihat 
Komunikasi Terapeutik Perawat Rohani Islam dalam Proses Penyembuhan Pasien di RSUD Ciamis berbagai aspek subjektif dari perilaku objek. Kemudian, peneliti melakukan penggalian data berupa bagaimana pemaknaan objek dalam memberikan arti terhadap fenomena terkait. Penggalian data ini dilakukan dengan melakukan wawancara mendalam kepada objek atau informan dalam penelitian, juga dengan melakukan observasi langsung mengenai bagaimana objek peneltian menginterpretasikan pengalamannya kepada orang lain.

Untuk mengetahui bagaimana Komunikasi Terapeutik yang dilakukan petugas Warois, maka perlu dibuatkan rumusan yang menjadi fokus penelitian agar pembahasanya terarah, serta dapat diketahui penjelasan secara lengkap dan rinci. Adapun yang menjadi focus penelitiannya adalah sebagai berikut : 1). Bagaimana proses komunikasi terapeutik oleh Perawat Rohani Islam (Warois)? 2).Bagaimana metode dan teknik komunikasi terapetik Warois ? 3). Bagaimana pesan komunikasi terapeutik Warois? 4). Bagaimana Keberhasilan komunikasi terapetik oleh Warois dalam proses penyembuhan pasien rawat inap di RSUD Ciamis?

\section{HASIL DAN PEMBAHASAN}

Tujuan penelitian ini adalah untuk mengetahui, menjelaskan dan membuktikan bahwa kegiatan perawatan rohani Islam yang dilakukan oleh petugas Warois di rumah sakit selama ini adalah termasuk jenis komunikasi terapeutik (Depkes, RI, 2009). Meskipun petugas Warois selama ini tidak menyadari atau mengetahuinya bahwa kegiatan perawatan rohani Islam itu ternasuk bagian dari komunikasi terapeutik Islam atau komunkasi terapeutik religious. Disebut komunikasi terapeutik Islam atau komunikasi terapeutik religius, karena materi (konten/pesan) komunikasinya, diambil dari ajaran agama Islam yang bersumber dari Al-Qur'an dan As-Sunnah.

Petugas perawatan rohani Islam (Warois) RSUD Ciamis tidak mengetahui tentang apa itu komunikasi terapeutik, apalagi kalau ditambah embel-embel komukasi teapeutik Islam atau komunikasi terapeutik religius. Hal tersebut sebagaimana di kemukakan oleh salah pelaksana seorang petugas Warois yang bernama Siti Fariroh, S.Ag. ketika di wawancara, dan ditanyakan apakah ibu mengetahui tentang komunikasi terapeutik? Maka jawabnya sebagai berikut :

"Tiih......., naon ari komunikasi terapetik teh ? Abdi mah teu terang tentang komunikasi terapeutik teh. Abdimah salaku petugas Warois mung ngalakukeun kaegiatan bimbingan ( E..e...e..eh ...apakah komunikasi terapeutik itu ? saya tidak tahu tentang komunikasi terapeutik. Saya sebagai petugas pelaksana Warois hanya melakukan kegiatan bimbingan) akhlaq, supaya pasien itu bisa menerima ujian penyakit dengan ikhlas, sabar dan bertawakal kepada Allah SWT. Dan mengajak pasein dan keluarga bersama-sama berdo'a kepada Allah SW'T., agar cepat diangkat kembali segala penyakit yang menimpanya, oleh Allah SWT dan disembuhkan, dari penyakitnya dengan kesembuhan yang tidak meniggalkan bekas. Setelah itu kemudian menanyakan apakah selama sakit dan dirawat di 
rumah sakit ibadah shalatnya libur atau tidak,? Kalau mejawab libur, maka saya memberikan arahan tentang pentingnya shalat bagi umat Islam, dan shalat itu tidak ada liburnya bagi laki-laki meskipun sedang sakit, kemudian membimbingnya bagaimana melaksanakan ibadah salat ketika sedang sakit, mulai dari bersuci, baik itu bersucinya dengan air atau dengan debu (tayamum). Selain itu memotivasi pasien agar selalu oftimis bahwa Allah akan menyembuhkannya. Adapun wujud motivasinya itu dengan bercerita pengalam pribadi atau dengan menceritakan kembali peristiwa yang dialami orang lain yang berhasil sembuh. Sekali lagi saya mah tidak tahu tentang komunikasi terapeutik, dan kalau tidak salah dengar itu ... mah wilayahnya perawat medis dan dokter. (Wawancara, Rabu, 28 Pebruari 2018).

Dilihat dari cara petugas Warois bersikap, serta teknik - teknik yang digunakan dalam berinteraksi dengan pasien, maka kegiatan interaksi petugas perawatan rohani Islam (Warois) dengan pasien rawat inap adalah merupakan aktivitas komunikasi terapetik, komunikasi yang biasa dilakukan oleh perawat medis, dan menjadi critical skill nya perawat medis. Meskipun petugas Warois tidak mengetahui tentang komunikasi terapeutik.

Kegiatan interaksi dan komunikasi petugas Warois dengan pasien rawat inap RSUD Ciamis, terbagi kepada beberapa layanan, yitu: (1) layanan tadqkirah(pemberian nasihat spiritual), (2) layanan bimbingan ibadah, (3) layanan bimbingan do'a dan dzikir serta (4) layanan bimbingan konseling. Semua layanan tersebut bertujuan untuk kesembuhan pasien. (Wawancara dengan petugas Warois, 12 Maret 2018).

Selain itu petugas Warois juga memberikan motivasi dan dorongan kepada pasien beserta keluarga, agar tetap semangat dan optimis, bersabar serta bertawakal kepada Allah SWT., dengan berkeyakinan bahwa do'a yang selalu dipanjatkan kepada-Nya akan dikabulkan, dengan dasar firman-Allah yang berbunyi :

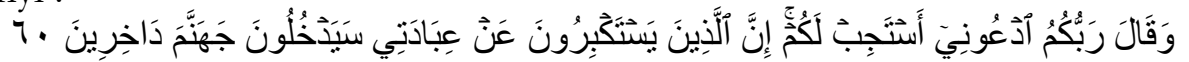

"Dan Tuhanmu berfirman, "Berdo'alah kepada-Ku, niscaya akan Aku perkenankan bagimu. Sesungguhya orang-orang yang sombong tidak mau menyembah- $\mathrm{Ku}$ akan masuk ke Neraka Jahanam dalam keadaan hina dina”.(Q.S. Al-Mu'min : 60).

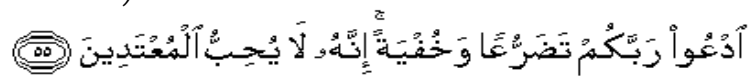

"Berdo'alah kepada Tuhanmu dengan rendah hati dan suara yang lembut. Sungguh, Dia tidak menyukai orang-orang yang melampaui batas" ( Q.S. alAraf :55) 


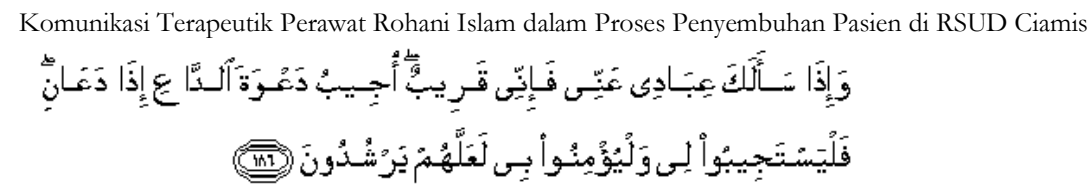

"Dan apabila hamba-hamba-Ku bertanya kepadamu tentang Aku, maka (jawab-lah), bahwasanya Aku adalah dekat. Aku mengabulkan permohonan orang yang berdo'a apabila ia memohon kepada-Ku, maka hendaklah mereka itu memenuhi (segala perintah)-Ku dan hendaklah mereka beriman kepada-Ku, agar mereka selalu ada dalam kebenaran." (Q.S. Al-baqarah : 186)

Dari tiga ayat tersebut di atas, pertama, bahwa Allah SW'T., memerintahkan kepada kita sebagai ummatnya untuk selalu memohon (berdo'a) kepada-Nya, dan menyebut orang yang tidak mau berdo'a kepada-Nya adalah orang yang sombong. Dan orang yang sombong akan di masukan ke dalam neraka Jahanam. Kedua, bahwa Allah SWT., memberitahukan kepada kita sebagai ummat-Nya cara berdo'a yang benar, yaitu dengan rendah hati dan suara yang lembut. Ketiga, bahwa Allah SWT., memberikan informasi kepada hambahamna-Nya,bahwa Dia (Allah) itu dekat dengan hamba-hama-Nya, dan berjanji akan mengijabah atau mengabulkan do'a, orang yang memohon kepada- Nya, tapi pada ayat yang ketiga yaitu, Q.S. Al-Baqarah : 186, Allah SWT., menambahkan dengan tiga syarat, yaitu : 1) apabila ia memohon hanya kepada Allah, 2) memenuhi segala perintah Allah, 3) beriman kepada Allah.

Allah SWT., akan mengangkat penyakit dari orang yang menderita sakit tanpa meninggalkan bekas, serta memberikan kesembuhan,karena Dia (Allah) Dzat Maha penyembuh yang sebenarnya, sebagaimana firman-Nya yang berbunyi :

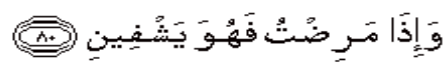

"Dan apabila aku sakit. Dialab (Allab) yang menyembubkan aku".(Q.S AlSyu'aro: 80).

Akan tetapi kebanyakan manusia tidak menyadari dan meyakininya, bahwa segala sesuatu yang terjadi itu atas kehendak dan taqdir-Nya. Artinya segala sesuatu yang terjadi atas makhluqnya telah tertulis di Lauh al-mahfudh.Maka untuk menyadarkannya diperlukan bimbingan rohani dan konselingreligius atau spiritual.Sebagai upaya untuk mengatasi defisit spiritual dan menghindari terjadinya distress spiritual.

\section{Proses Komunikasi Terapeutik Perawat Rohani Islam}

Pada wawancara selanjutnya ditanyakan kepada Hj. Siti Rahmah S.Ag. (45 Th), pelaksana petugas Warois, bagaimana cara petugas Warois menginterpensi pasien dan memulai berkomunikasi dengan pasien, serta bagaimana berlansungnya proses komunikasi terapeutik tersebut?

"Yah....cara memulai berkomunikasi dengan pasien dan keluarga, mengikuti petunjuk teknis dari standar oprasional prosedur (SOP), yang telah 
disetujui oleh pimpinan Rumah Sakit, sebagaimana yang tertera dalam SOP kunjungan ke pasien rawat inap. Yaitu meminta izin dahulu kepada petugas jaga ruangan sambil meminta informasi tentang data pasien yang dirawat pada ruangan tersebut untuk bahan kajian sebelum masuk ruang perawatan, setelah itu masuk ruang perawatan dengan menyapa pasien dan keluarga dengan mengucapkan salam dan memperkenalkan diri. Kemudian meminta izin kepada pasien atau keluarga untuk memberikan layanan rohani sambil bersalaman dengan setiap pasien, dan ketika bersalamam petugas Warois membacakan do'a kesembuhan bagi pasien.Maka proses interaksi komunikasi terapeutik Warois terjadi atau berlansungdiawali dengan tahapan orientasi atau perkenalan antara petugas Warois dengan pasien dan keluarga. Pada tahapan ini terjadi penggalian informasi dan data pasien oleh petugas Warois. Tahap selanjutnya penentuan konten pesan terapeutik yang bagaimana yang harus disapaikannya agar dapat direspon dan berefek serta dapat memberi terapi sekaligus. Yah, .. sudah barang tentu konten pesan nya berupa nasihat (tad₹kirah), bimbingan ibadah, bimbingan do'a dan dzikir. Medianya melalui anggota tubuh yaitu mulut dan audio. Saluranya atau chenel nya adalah ruang perawatan (Kutipan Wawancara, Sabtu, 03 Maret 2018).

Maka dengan demikian proses komunikasi terapeutik petugas perawat rohani Islam (Warois) adalah berlangsungnya serangkaian peristiwa interaksi penyampaian pesan dari petugas Warois sebagai komunikator kepada pasien rawat inap sebagai komunikan (penerima pesan), sehingga dapat menciptakan suatu persamaan makna antara komunikan dengan komunikatornya. Proses komunikasi terapeutik petugas Warois diawali dengan pra interaksi, perkenalan (orintasi), berlansungya penyampaian pesan atau pertukaran makna (interaksi komunikasi), dan pengakhiran komunikasi (penutup) dengan do'a. Proses tersebut bertujuan untuk menciptakan komunikasi yang memiliki pengaruh positif (terapi) bagi pasien rawat inap, sehingga memberikan efek kesembuhan.

Proses Komunikasi petugas Warois, dilihat dari strateginya seirama dengan model proses komunikasi Lasswell, dimana terdapat lima pertanyaan yang perlu dijawab dalam proses komunikasi, yaitu who(siapa), says what (mengatakan apa), in wich channel (dalam media apa), to whom (kepada siapa), dan what effect (apa efeknya). Sebagaimana sekema dibawah ini

Tabel 5.1

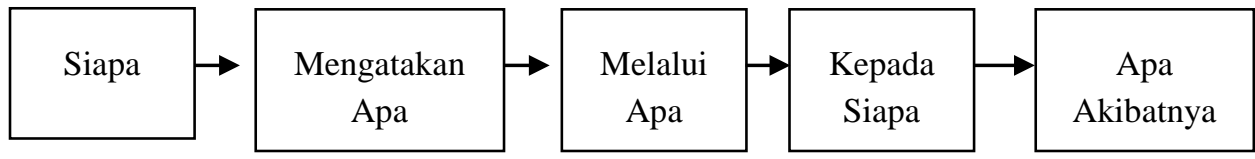

Model Komunikasi Lasswell (Cangara, 2016: 46) 
Komunikasi Terapeutik Perawat Rohani Islam dalam Proses Penyembuhan Pasien di RSUD Ciamis

Proses komunikasi yang dilakukan oleh petugas Warois memiliki pengaruh psikologis, kerena dapat myentuh perasaan atau emosi pasien, sehingga menjadi spirit atau motivasi dan dorongan semangat untuk sembuh, maka komunikasi tersebut dapat menjadi terapi. Karena tujuan utama dari interaksi komunikasi petugas Warois dengan pasien rawat inap adalah untuk memberikan pengaruh positif (positive effect) terapi dalam proses penyembuhan. Hal ini sama dengan model proses komunikasi Lasswell,yang sangat menekankan terhadap pengaruh pada khalayak atau audien. Sebab Lasswell melihat bahwa suatu proses komunikasi selalu mempunyai efek atau pengaruh (Cangara, 2016: 46).

Komunikasi memegang peranan sangat penting dalam pelayanan keperawatan, bahkan dapat dikatanan komunikasi merupakan kegiatan mutlak dan menentukan bagi hubungan / interaksi perawat - pasien untuk menunjang kesembuhan pasien (Khotimah, Marsito, \& Iswati, 2012: 74). Perawat yang memiliki kecakapan dalam komunikasi intrapersonal dengan pasiennya, akan mengembangkan perasaan pasien sebagai manusia yang utuh. Komunikasi terapeutik akan terjadi manakala terdapat kesadaran diri, klarifikasi nilai dan proses hubungan bertanggung jawab antara perawat dengan pasien (Akhmawardani, 2013).

Komunikasi terapeutik merupakan komunikasi yang direncanakan secara sadar, bertujuan dan kegiatannya dipusatkan untuk kesembuhan pasien. Komunikasi terapeutik merupakan komunikasi professional yang mengarah pada tujuan yaitu penyembuhan pasien. Komunikasi merupakan proses kompleks yang melibatkan perilaku dan memungkinkan individu untuk berhubungan dengan orang lain dan lingkungan sekitar (Taviyanda, 2010: 75). Komunikasi Terapeutik merupakan komunikasi yang direncanakan secara sadar dan bertujuan serta kegiatannya difokuskan untuk kesembuhan pasien, dan merupakan komunikasi professional yang mengarah pada tujuan untuk penyembuhan pasien yang dilakukan oleh perawat atau tenaga kesehatan lainnya. Komunikasi terapeutik tidak dapat berlangsung dengan sendirinya, tetapi harus direncanakan, dipertimbangkan, dan dilaksanakan secara professional. Melakukan proses komunikasi terapeutik seorang perawat harus mengetahui dasar, tujuan, manfaat, proses atau teknik dan tahapan komunikasi dan melaksanakannya dengan sikap yang benar di rumah sakit (Shintana \& Siregar, 2012: 1).

Kegiatan komunikasi petugas perawatan rohani Islam (Warois) dilakukan secara sadar dan terencana.Sehinggaketika terjadi interaksi komunikasi dengan pasien dan keluarga yang menunggunya, petugas Warois sangat memperhatikan konten pesan yang disampaikannya. Adapun konten pesan yang disampaikannya meliputi: tadækirah(bimbingan rohani/nasihat), bimbingan ibadah, do'a, dzikir dan konseling. Semua materi tersebut ketika disampaikan harus mampu memberi pengaruh terapi atau berefek positif bagi proses penyembuhan pasien.

Agar tujuan dari komunikasi terapeutik itu tercapai, maka langkah - 
Ibin Hasani

langkah yang dilakukan petugas Warois dalam proses komunikasi tersebut adalah sebagai berikut:

Persiapan Diri., mempersiapkan diri sebelum berinteraksi secara lansung dengan pasien adalah hal yang sangat penting dilakukan oleh petugas Warois, karena dapat membantu kesiapan mental (psikis) dan percaya diri. Persiapan diri dapat dilakukan dengan cara melakukan diskusi dengan diri sendiri, yang dalam ilmu komunikasi disebut dengan komunikasi intrapribadi, atau dikenal dengan internalisasi. Persiapan diri yang dilakukan oleh petugas Warois, memiliki kesamaan dengan konsep analisis diri yang dikemukakan oleh G. Stuart. W. dan Laraia M. T (2001) yaitu:' bahwa perawat sebelum berkomunikasi langsung dengan pasien harus terlebih dahulu melakukan analisis diri, yang meliputi kesadaran diri, klasifikasi nilai, eksplorasi perasaan, kemampuan menjadi model, panggilan jiwa (altruism), etika dan rasa tanggung jawab' (Suryani, 2017: 23) . Lebih jauh Stuart. W. dan Laraia M. T (2001) mengatakan,bahwa melalui kesadaran diri itu diharap perawat sebagai instrumen dalam komunikasi terapeutik harus mampu mengenal pribadinya dengan baik. Ia harus sadar siapa dirinya. Sebagaimana pada tabel berikut :

Tabel. 5.2

\begin{tabular}{cc}
\hline I & II \\
Diketahui oleh diri & Hanya diketahui oleh \\
sendiri dan orang lain & orang lain \\
III & IV \\
Hanya diketahui oleh & Tidak diketahui oleh \\
diri sendiri & siapapun \\
\hline
\end{tabular}

Mengenal diri Sendiri Model Johari Window (Sinaulan, 2012: 247).

Dengan kesadaran diri ini diharapkan perawat dapat menerima secara obyektif perbedaan dan keunikan klien, karena kesadaran diri berpengaruh terhadap komunikasi terapeutik (Sinaulan, 2012: 247).

Tentang kesadaran diri, Johari Window mengemukakan teori yang dikenal sebagai teori Self Disclosure sebagaimana yang digambarkan dalam table tersebut di atas. Pada tabel tersebut menggambarkan terjadinya perubahan satu kuadran yang akan berpengaruh pada kuadran yang lain. Beberapa kemungkinan yang dapat terjadi dari pergeseran masing-masing kuadran antara lain sebagai berikut (Littlejohn 2005: 321).J.H. Sinaulan (2012 : 248), menafsirkan tabel teori kesadaran diri Johari Window sebagai berikut :

Apabila kuadran I diperbesar maka individu ini cenderung extrovert, bersikap terbuka pada orang lain dengan ditandai ciri-ciri yang meliputi periang,mudah akrab, ramah, pemurah, banyak teman dan menyenangkan. Apabila kuadran II diperbesar, maka individu ini suka menonjolkan diri, merasa super, kurang mampu introspeksi sehingga selalu merasa benar, dan tidak mampu mengenali diri sendiri. 
Komunikasi Terapeutik Perawat Rohani Islam dalam Proses Penyembuhan Pasien di RSUD Ciamis

Apabila kuadran III diperbesar, maka individu ini nampak introvert, pendiam, suka menyendiri, dan lebih banyak menyimpan rahasia. Apabila kuadran IV diperbesar, maka individu ini tidak banyak dikenal orang lain, namun ia banyak mengetahui tentang orang lain sehingga tidak banyak orang yang mengenal dirinya. Orang lain bahkan tidak mengenal dirinya sendiri.

Kesadaran seseorang dapat dikembangkan dengan cara mengenali diri sendiri, belajar dari pihak lain, dan bersikap terbuka terhadap informasi atau perubahan yang terjadi (Suryani, 2017 : 24). Awarenees (kesadaran) berarti bahwa pesan yang telah dibuat menimbulkan kesan kepada pembaca atau penonton yang kemudian dapat membantu mengidentifikasi pembuat pesan. Knowledge ( Pengetahuan) (Sudiansyah, 2018: 40). Kesadaran ini menentukan pola interaksi yang dibangun antara komunikator dan komunikan, antara petugas Warois dengan pasien dan keluarga. Dari kesadaran diri yang baik dapat tercipta hubungan terapeutik yang saling memuaskan.

Mencari Informasi dan Data Pasien, mengetahui informasi dan data pasien yang ada di ruang perawatan yang akan dikunjungi, merupakan hal yang sangat bermanfaat bagi petugas Warois, karena dapat memberikan deskripsi (gambaran) tentang kondisi pasien, sehingga petugas Warois memiliki persiapan untuk menentukan layanan yang akan diberikan dan dianggap lebih tepat. Dalam hal ini konten pesan komunikasinya. Untuk mengetahui data dan informasi pasien dapat dilakukan dengan cara menanyakan kepada perawat jaga ruangan tersebut. Sebagaimana yang terdapat dalam Standar Oprasional Prosedur (SOP) Warois dalam berkunjung ke ruang perawatan. Adapun informasi dan data pasien yang diperlukan meliputi: nama pasien, umur pasien, alamat pasien, pekerjaan pasien, jenis penyakit yang diderita (hasil diagnosa dokter).

Masuk Ruang Perawatan dan Melakukan Perkenalan, setelah memiliki informasi dan data pasien yang ada di ruang perawatan tersebut di anggap cukup, petugas Warois masuk ke ruang perawatan dengan menyapa pasien sambil mengucapkan salam, kemudian mensalami pasien satu persatu, setelah itu petugas Warois memperkenalkan diri kepada pasien rawat inap dan keluarga yang menunggunya serta meminta izin kepada pasien dan keluarga umtuk memberikan layanan bimbingan rohani.

Melakuan Interaksi komunikasi interpersonal dengan pasien dan keluarga, petuagas Warois melakukan interaksi komunikasi antar peribadi dengan setiap pasien yang dirawat, untuk menggali data dan informasi, apa sebenarnya yang sangat dibutuhkan pasien dari segi rohaninya. Hal tersebut dilakukan dengan cara bertanya (questioning), baik itu berupa pertanyaan yang sifatnya terbuka (opened question) maupun pertanyaan tertutup (closed ended question), mendengarkan (listening) dan memperhatiakan keluhan serta curahan hati pasien.

Petugas Warois memberikan layanan tadzkirah(tausiab) berupa nasihat, bimbingan ibadah, do'a, drikir dan konseling, pemberian layanan tadykirah, bimbingan ibadah, do'a, dzikir dan konseling, dilakukan oleh petugas Warois setelah terjadinya 
perkenalan, wawancara atau interview dan mendengarkan keluhan-keluhan pasien.

Melakukan Do'a bersama, setiap mengakhiri dan menutup pertemuan dengan pasien sebelum berpisah petugas Warois mengajak kepada pasien dan keluarganya untuk berdo'a bersama, memohon keberkahan(kebaikan) dan kesembuhan kepada Allah SWT, bagi semua pasien yang sedang dirawat.

Dengan demikian dapat ditarik kesimpulan bahwa pengertian komunikasi terapeutik perawatan rohani Islam (Warois) adalah segala kegiatan interaksi komunikasi petugas perawatan rohani Islam (Warois) dengan pasien rawat inap, yang dilakukan secara sadar dan terencana, dengan tujuan untuk kesembuhan pasien. Kegiatan komunikasi terapeutik tersebut dilakukan oleh petugas perawatan rohani Islam (Warois) pada saat melakukan bimbingan rohani kepada pasien di ruang perawatan. Selain itu sebagai upaya untuk menjaga dan memelihara aktivitas ruhaniyah insaniyah pasien, meskipun dalam keadaan sakit.

Konten pesan pada komunikasi terapeutik petugas perawatan rohani Islam (Warois) dilihat dari segi materi pesan yang disampaikannya, dapat dibagi menjadi 4 (empat) kelompok, yaitu :a). Bimbingan ibadah mahdhah (yang berhubungan langsung dengan Allah) seperti shalat, shaum dan ibadah haji. b). Bimbingan tadzkiroh (nasihat dan akhlaq). c). Bimbingan do'a dan dzikir. d). Bimbingan konseling.

\section{Bimbingan Ibadah Mahdhah}

Bimbingan ibadah mahdhah adalah proses pemberian bantuan terhadap individu agar dapat melaksanakan kewajiban (ibadah yang langsung berhubungan dengan Tuhan secara vertikal) seorang terhadap Tuhannya sebagai ummat beragama, sesuai dengan aturan syari'at (Sarbini, 2002: 3). Sehingga kewajiban yang melekat pada dirinya dapat tertunaikan sesuai syari'at dalam arti terbebas dari taklif.

Untuk sampai terlaksananya kewajiban ibadah mahdhoh yakni,shalat fardlu yang lima waktu, maka ada tahapan - tahapan yang harus dipenuhi oleh seseorang yaitu: thaharah (bersuci). Thaharoh itu ada dua jenis yaitu: Thaharah dari hadas kecil ( buang hajat kecil dan buang hajat besar) dengan cara istinja, wudhu atau tayamum. dan Thaharah dari hadas besar ( keluar mani, haid, dan berjima suami istri) cara mensucikannya dengan mandi Janabat.

Maka untuk orang yang sedang menderita sakit diperlukan bimbingan atau bantuan, agar dia dapat melaksanakan thaharah sesuai dengan syari'at, sehingga ibadah yang dikerjaknnya menjadi syah.

Kebanyakan pasien rawat inap RSUD Ciamis dan keluarga yang menunggunya, ketika dilakukan observasi tanggal 06, 09, dan 10 Maret 2018, diruang perawatan VIP Hasan Sobari, Bougenvill, dan Wijaya Kusuma, ketika ditanya oleh petugas Warois tentang bagaiman bapak/ Ibu pelaksanaan amalan ibadah shalatnya, ketika sedang sakit dan dirawat di RSUD Ciamis seperti 
Komunikasi Terapeutik Perawat Rohani Islam dalam Proses Penyembuhan Pasien di RSUD Ciamis sekarang ini, libur atau tidak? Maka dari beberapa jawaban yang terkumpul, setelah dilakukan pengelompokan ada tiga macam jawaban, yaitu:

Pasien 1 : Abdimah mung ngahormat waktu wungkul, da kumaha ieu badan abdi kalotor kunanjis, pakai pamper, jadi BAK sareng BAB, dina pamper. Engke wae upami tos damang di qadhaan atanapi di etang teras dipidyahan.(Saya hanya menghormati waktu saja, sebab bagaimana lagi badan saya kotor oleh najis, memkai pamper. Jadi buang air kecil dan buang air besar pada pamper tersebut. Nanti saja kalau sudah sembuh di qadha shalatnya atau dihitung saja berapa kali tidak melaksanakan shalat, kemudian dibayar dengan fidyah). (Kutipan wawancara petugas warois $\mathrm{Hj}$. Dra. Iik Iklimah $56 \mathrm{Th}$, dengan pasien Ny. Khodijah 50 Th. diruang perawatan Mawar, Selasa 06 Maret 2018)

Pasien 2 : Abdi mah libur ayenamah solatna, da barabe panangan sareng BAK na nganggo selang janten najis na teras teu liren-liren. Wios diengke di qadla dibumi upami tos damang.(Sekarang ini, salat saya libur, sebab susah, tangan dan buang air kecil-nya pakai selang jadi najisnya terus menerus, tidak henti-henti. Biar nanti diqadha saja di rumah kalau sudah sembuh). (Kutipan wawancara petugas Warois $\mathrm{Hj}$. Siti Rahmah S.Ag., dengan pasien rawat inap di ruang perawatan paviliun Hasan Sobari Ny. Sa'adah 54 Th. (Observasi dan wawancata, Kamis 09 Maret 2018)

Pasien 3 : Al-Hamdulillah teu libur shalat mah, mung wudhuna digentos ku tayamum.( Al- Hamdulillah shalat saya tidak libur, hanya saja wudlunya diganti dengan tayamum).(Kutipan wawancara dengan pasien rawat inap di ruang perawatan paviliun Hasan Sobari Tn. H. Maman 56 Th. Sabtu 10 Maret 2018)

Selanjutnya petugas Warois memberikan pemahaman kepada pasien dan keluarga yang menunggunya, dengan menjelaskan secara seksama tentang keutamaan danpentingnya pengamalan ibadah shalat bagi ummat Islam, meskipun sedang dalam keadaan sakit, selagi ingatannya masih normal (sadar). Kemudian petugas Warois menjelaskan rukhsoh - rukhsoh yang ada dalam Shalat Fardlu (yang lima waktu) bagi orang yang sedang sakit. Selanjutnya petugas Warois menjelaskan dan mencontohkan cara beristinja atau bersuci dan bertayamum kepada pasien dan keluarga yang menunggunya dan cara memberikan bantunan untuk melakukan wudhu dan tayamum bagi orang yang tidak bisa melakukannya sendiri.

Petugas Warois menjelaskan dan memperagakan tata cara pengamalan shalat bagi orang sakit dengan berbagai cara. Sehingga nantinya, sakit yang dideritanya dan yang lainnya, tidak lagi menjadi alasan tertinggal atau terlewatkannya ibadah shalat fardlu. Pada akhirnya diharapkan kewajiban ibadahmahdhah yang dikerjakan oleh pasien itu bukan lagi merupakan suatu beban, tapi justru menjadi suatu kebutuhan baginya.

Penyampaian pesan-pesan tersebut dilakukan melalui komunikasi verbal dan non verbal. Seperti halnya memahamkan kewajiban shalat fardlu yang lima 
waktu bagi orang Islam. Shalat bagi orang Islam merupakan kegiatan ibadah mahdhh (ibadah yang langsung berhubungan dengan Allah), tidak boleh ada yang tertinggal atau terlewatkan. Kegiatan ibadah mahdhoh tersebut apabila dikerjakan dengan penuh kekhusuan akan menjadikan jiwa merasa tenang, karena dalam shalat terjalin suatu interaksi komunikasi antara mahkluq dengan khaliq secara langsung (komunikasi transenden), sehingga terbangun dalam diri pasien emosi positif, yang membuat pasien merasa dekat dengan sang Khaliq Allah SWT. Orang Islam berkeyakinan bahwa Allah SW'T., akan mengabulkan do'anya, yaitu akan segera menyembuhkan dari sakit yang dideritanya. Karena Allah-lah sang Maha Penyembuh sebenarnya, sebagaimana yang sampaikan oleh petugas perawatan rohani Islam (Warois).

\section{Bimbingan Tadzkiroh (Nasihat dan Akhlaq).}

Bimbingan tadzkirah, maksudnya layanan bimbingan dengan tausiah (nasihat) atau ceramah singkat yang diberikan kepada pasien rawat inap RSUD Ciamis. Semua pasien harus mendapat layanan bimbingan tadzkirah, agar selalu ingat dan dekat kepada Allah SWT. Dengan adanya layanan tadzkirah, diharapkan pasien dapat termotivasi dan terdorong semangatnya untuk sembuh, sehingga emosinya tetap stabil. Karena dengan selalu taqorub kepada Allah hati akan menjadi tenang dan damai sebagai mana firman Allah SWT.

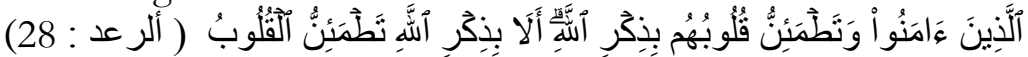

Yaitu: orang-orang yang beriman dan hati mereka manjadi tenteram dengan mengingat Allah. Ingatlah, hanya dengan mengingati Allah-lah hati menjadi tenteram. (Q.S.13: 28).

Penekanan konten pesan tiap pasien berbeda-beda, tergantung dari kondisi psikologis pasien dan sakit yang di deritanya. Seperti yang terjadi pada pasien Tuan Ujang Abdullah (48 Tahun), dirawat diruang perawatan khusus bagian saraf (Ruang Mawar) RSUD Ciamis, ia merasakan kakinya kesemutan terus-menerus, dan sulit untuk digerakan. Berdasarkan hasil pemeriksaan dokter, Tuan Ujang di diagnose terkena stroke ringan. Begitu mendengar ponis stroke ringan, Tuan Ujang Abdullah diam seribu basa karena mengalami shock dan depresi, jiwanya dilanda berbagai macam kekhawatiran dan ketakutan.

Maka ketika petugas Warois datang berkunjung ke ruangan tersebut untuk memberikan layanan bimbingan rohani, dengan menyapa sambil membaca salam dan do'a. Petugas Warois kemudian menghampiri Tn. Ujang dengan bermushafahah (berjabat tangan) agak lama sambil membaca do'a khusus kesembuhan bagi pasien, selanjutnya terjadilah komanukasi interpersonal anatara petugas Warois dengan pasien (Tn. Ujang), dalam interaksi tersebut Tn. Ujang curhat tentang sakit yang dideritanya. Petugas petugas Waroi, mendengarkannya dengan penuh perhatian, sambil berdiri jongkok menhadap pasien, setelah tuan Ujang selesai berbicara, petugas Warois memberikan 
Komunikasi Terapeutik Perawat Rohani Islam dalam Proses Penyembuhan Pasien di RSUD Ciamis semangat dan motivasi serta dorongan agar pasien dan keluarga tetap tenang, sabar, tawakal dan terus memohon dengan berdo'a kepada Allah SWT., agar cepat disembuhkan kemabli. Dalam dialog tersebut petugas Warois mengajukan beberapa pertanyaan tertutup (opened closed quetion) kepada pasien tersebut, yaitu :

Bagaimana tidurnya semalam ? Bagaimana makannya masuk apa tidak ? Bagaimana ingatannya, masih normal atau terganggu maksudnya ada yang lupa apa tidak ? Apa yang masih dirasakan sekarang ?Apakah bacaan shalat masih ingat? Bagaimana pengerjaan shalat di rumah sakit terlewatkan apa tidak?

Pertanyaan nomor 3, 5 dan 6 adalah yang menjadi fokus perhatian petugas perawatan rohani Islam (Warois), yaitu untuk memastikan bahwa pasien tersebut masih terkena taklif wajib mejalankan ibadah shalat atau tidak dan telah hilang kewajiban melaksanakan shalatnya karena hilang ingatanya (kesadarannya). Apabila jawaban masih ingat (sadar) tidak ada yang lupa, kemudian jawaban pertanyaan nomor 5 ia lupa, maka kepada keluarga penunggu diminta untuk mengingatkannya ketika waktu shalat tiba, dan membantunya mengingatkan kembali bacaan shalat yang ia lupa dengan cara keluarga penunggu membacakan dengan keras bacaan shalat dari awal sampai selesai seolah - olah ia sedang melaksanakan salat, sipasien shalat dengan mengikuti bacan yang dibacakan penunggu. Apabila pertanyaan no. 5 jawabannya masih ingat tapi tidak melaksanakan shalat karena berbagai alasan, maka petugas Warois membimbing dan memberikan konseling agar pasien tersebut dengan kesadarannya mau melaksanakan shalat meskipun sedang sakit dan dirawat di rumah sakit. Kemudian pertanyaan nomor 6 apabila dijawabannya Al-Hamdulillah tidak ada yang terlewatkan. Maka petugas Warois memberikan aplaus yang edukatif dengan mendo'akan "Semoga segala amal ibadah yang dikerjakannya menjadi washilab(sebab) terijabahnya do'a.

Maka setelah itu petugas Warois memberikan tausiah singkat dengan tema 'faedah bersuci'. Bahwa wudhu apabila diamalkan sesuai dengan contoh yang diajarkanRasullah SAW., dapat mencegah berbagai macam penyakit salah satunya dapat mencegah terjadinya stroke itu tadi.

Seoerti halnya diriwayatkan dari Humran bahwasanya Usman meminta air wudlu. Ia membasuh kedua telapak tangannya tiga kali, lalu berkumur dan menghirup air dengan hidung dan menghembuskannya keluar, kemudian membasuh wajahnya tiga kali. Kemudian membasuh tangan kananya hingga siku-siku tiga kali kemudian tangan kirinya pun juga demikian tiga kali. Kemudian mengusap kepalanya, kemudian membasuh kaki kanannya hingga mata kakinya tiga kali, kemudian kaki kirinya pun begitu pula. Kemudian berkata Usman: Saya melihat Rasulullah SAW, berwudu seperti wudlu ini” (H.R. Mutafaq Alaih).

Penjelasan tentang mengusap kepala yang lengkap dalam wudlu terdapat pada hadis yang diriwayatkan oleh Abu Dawud dan Nasa'i, yaitu:

Dari Abdulllah Ibnu Amr, tentang cara berwudlu, ia berkata : Kemudian 
Ibin Hasani

beliau mengusap kepalanya dan memasukkan kedua jari telunjuknya ke dalam kedua telinganya dan mengusap-ngusap bagian luar kedua telinganya dengan kedua ibu jarinya. ( H.R. Abu Daud dan An-Nas'i)

Pada hadis tersebut di atas yang mengisyaratkan dapat menjaga terjadinya stroek ditunjukkan oleh : 1) lafad إستنشق(menghirup air ke dalam hidung) karena menghirup air kedalam hidung dapat memperlebar pembuluh darah di kepala, selain itu dapat membersihkan kotoran debu yang terhirup ketika bernafas dan mengendap di rongga hidung dan dapat mempertajam daya penciuman. 2) lafad ومسح بإبهاميه ظاهر أذ نيه (dan mengusap dengan kedua ibujarinya bagian luar kedua telinganya) dapat menyembuhkan banyak penyakit dalam tubuh.

\section{Bimbingan Do'a dan Dzikir.}

Dalam Islam do'a adalah salah satu tugas agama yang sangat penting, dan berkedudukan sangat mulia. Do'a juga bisa dipandang sebagai pintu yang besar di antara pintu - pintu ibadah yang lain, dalam memperhambakan diri kepada Allah SWT dan memperlihatkan ketundukan jiwa kepada - Nya (Sambas \& Sukayat, $2002: 20)$.

Syukriadi Sambas (2002), menyebutkan dalam hadis yang diriwayatkan oleh Imam Turmudzi di katakan, bahwa: “ Do’a itu adalah otaknya Ibadah”, do'a dipandang sebagai otaknya ibadah karena ia merupakan bentuk ibadah yang jelas sekali memperlihatkan unsur penghambaan kepada Allah dan sangat berhajatnya hamba kepada - Nya, terwujudlah posisi bahwa Allah adalah tempat meminta dan tempat memohon, sedangkan si hamba adalah makhlik yang hina dina dan selalu dalam kekurangan (Sambas \& Sukayat, 2002: 21).

Layanan bimbingan do'a dan dzikir diberikan oleh petugas perawatan rohani Islam kepada pasien rawat inap dan keluarga yang menunggu dengan tujuan untuk memberikan kekuatan secara moril (bathin) dalam menghadapi musibah atau ujian sakit yang menimpanya. Syukriadi Sambas dan Tata Sukayat, (2002: 30) menyebutkan bahwa do'a yang dilakukan seorang hamba mengandung beberapa fungsi dalam hidup dan kehidupannya. Di antara fungsi do'a itu adalah sebagai berikut:

1). Do’a sebagai pencerminan kehambaan makhluk di hadapan Khalik. 2). Do'a merupakan salah satu bentuk Ibadah, karena merupakan perintah Allah. 3). Do'a merupakan proses solusi problem kehidupan baik spiritual maupun material. 4) Do'a sebagai pengendali pusat gerak spiritual yang merupakan refleksi lahir melalui do’a dan dzikir. 5). Do’a sebagai bagian dari "qadar" yang telah ditetapkan bagi seseorang.

Isep Zaenal Arifin, (2015: 121) menyebutkan bahwa, bagi orang sakit do'a memiliki dua fungsi, yaitu fungsi ikhtiar dan fungsi obat. Do'a merupakan salah satu ikhtiar, yaitu memohon pertolongan Allah, selai ia juga berikhtiar dengan cara mencari pengobatan. Sedangkan fungsi do'a sebagai obat telah banyak 

dibuktikan oleh berbagai penelitian.

Layanan bimbingan do'a dan dzikir yang diberikan oleh petugas Warois diharapkan dapat memenuhi kebutuhan spiritualitas pasien dalam menghadapi sakit, sehingga dapat menghadirkan kekuasaan dan pertolongan Allah SWT., pada hambanya. Dengan do'a dan dzikir diharapkan dalam diri pasien tumbuh kekuatan spirtualnya, sehingga mempercepat proses penyembuhan karena kesejateraan spiritualnya terpenuhi (Arifin, 2010: 156). Karena terapi dengan do'a yang diambil dari al-Qur'an sesungguhnya memiliki efek terapi terhadap berbagai penyakit fisik termasuk kepada penyakit fisik pasien sehingga dapat membantu kesembuhan pasien. Hal ini didasarkan pada Qur'an, Surat 17 (AlIsra) : 82, dan Qur'an Surat 44 (Fushilat): 44

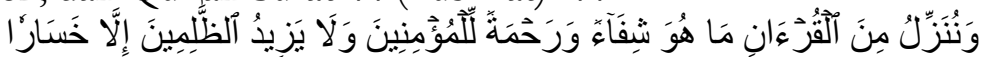

Dan Kami turunkan dari Al Quran suatu yang menjadi penawar dan rahmat bagi orang-orang yang beriman dan Al Quran itu tidaklah menambah kepada orang-orang yang zalim selain kerugian.

Ibnu Qayyim al-Zawzi dalam tafsir al-Qayim, menjelaskan, bahwa yang dimaksud "Syifa" (obat penawar penyakit), pada ayat tersebut adalah alqur'an itu berfungsi sebagai obat penawar berbagai penyakit, baik penyakit jasmani maupun penyakit ruhani. Karena menurut Ibnu al- Qayyim, perkataan " Min" pada ayat 82 Q.S. 17 : 82 maknanya "lilbayyan" (sebagai pejelasan) bukan" litab’id " (menunjukan sebahagian) (Sambas \&Sukayat, 2002: 202). Selanjutnya Ibnu Qayyim al-Zawzi menyebutkan bahwa do'a memiliki pengaruh terhadap penyembuhan peyakit, karena do'a pada hakikatnya merupakan energi immateri yang diarahkan kepada penyakit, atas dasar itu maka dapat dirumuskan ketentuan - ketentuan sebagai berikut: (1) Bobot energi do'a lebih besar dari penyakit, maka peluang sembuh lebih besar.Antara bobot energi do'a dengan penyakit seimbang (sama), maka peluang sembuh lambat. (2) Bobot penyakit lebih besar dari bobot energi do'a, maka peluang sembuh kecil. (3) Mengacu pada tiga prinsip tersebut, maka dalam melakukan do'a untuk penyembuhan penyakit, maka petugas atau siapapun yang melakukannya harus menyadari bahwa upaya - upaya dalam bentuk do'a yang dilakukannya harus memiliki volume yang lebih tinggi dan lebih besar dibanding dengan penyakit yang akan dido'akan untuk disembuhkannya itu (Sambas \& Sukayat, 2002: 205-206).

Kegiatan layanan bimbingan do'a dan dzikir dilakukan setelah bimbingan tadqkirah. Bimbingan do'a secara khusus dilakukan apabila sudah melakukan kegiatan bimbingan konseling, serta apabila ada permintaan di visite (kunjungi) oleh petugas Warois. Kebanyakan pasien rawat ini lebih senang dengan layanan bimbingan do'a dibandingkan dengan bimbingan ibadah. Layanan bimbingan do'a dan dzikir dilakukan untuk membantu pasien yang mengalami stress akibat sakit yang dideritanya, sehingga tidak bisa tidur, dan berteriak - teriak serta marah - marah kepada perawat dan keluarga yang menunggunya. Seperti yang terjadi pada pasien di ruang perawatan VIP RSUD Ciamis, pasien tersebut 
bernama Tn. Cucu (62 Tahun), pensiunan PNS, dengan diagnose penyakit Tumor lambung. Ia ketika sedang kesakitan suka berteriak-teriak, sehingga mengganggu pada pasien lain, hal ini membuat perawat jaga ruangan jadi jengkel akibat ulah dari pasien yang bernama Tn. Cucu tersebut.

Perawat jaga VIP memanggil petugas Warois untuk diminta menenangkannya agar tidak berulah demikian meskipun sedang kesakitan.Petugas Warois setelah dipanggil untuk diminta bantuannyaoleh perawat jaga ruangan VIP mendatangi pasien tersebut, sebelumnya petugas Warois meminta data informasi tentang pasien Tn. Cucu,untuk melakukan komunikasi intrapribadi. Setelah itupetugas Warois mendatangi ruang perawatan pasien Tn. Cucu, petugas Warois menyapanya dengan mengucapkan salam terus berjabat tangan sambil mengucapkan do'a kesembuhan untuk pasien ketika sedang bersalaman (berjabatan tangan). Kemudian setelah itu terjadilah interaksidan komunikasi interpribadi secara pace to pace (tatap muka),petugas Warois dengan sabar dan penuh perhatian mendengarkan apa yang disampaikan Tn. Cucu, dengan sesekali menganggukkan kepala dan berkomentar seperlunya sebagai jawaban pertanyaan yang diajukan pasien. Setelah pasien selesai berbicara atau curhat, petugas Waroismemberikan bimbingan konseling kepada pasien Tn. Cucu, semoga ujian penyakit yang menimpanya menjadi magfirah atas segala kealfaan, kesalahan dan kehilafan selama ini, serta petugas Warois berpesan kalau sedang terasa sakit yang hebat agar jangan berteriak-teriak lagi, tapi berdzikir, takbir dan beristigfar kepada Allah SWT., sambil berdo'a, memohon kepada -Nya, agar menghilangkan rasa sakit tersebut.

\section{Bimbingan konseling.}

Secara definisi Bimbingan konseling adalah semua jenis bantuan dalam membantu orang untuk mengatasi semua jenis masalah yang dihadapininya seperti maslah emosi atau spiritual. Konseling tidak terbatas pada distres mental atau gangguan mental tapi mencakup segala hal problema hidup. Definisi lain konseling adalah, "suatu kegiatan atau aktifitas yang di dalamnya terdapat satu orang yang membantu dan satu orang lain yang menerima bantuan dan penekanan bantuan tersebut adalah untuk memampukan orang lain menemukan pemecahan masalah atau melihat keadaan tertentu yang akan mereka tangani, atau untuk memampukan mereka agar lebih dapat mengatasi masalah dalam hidup" (Morrison \& Burnard, 2009: 120),.

Bimbingan konseling yang dimaksud pada kegiatan perawatan rohani Islam (Warois) adalah layanan yang ditujukan untuk membantu pasien rawat inap khususnya, dalam memberikan solusi atas problematika hidup yang dialaminya, baik itu mengenai peroblem yang ia hadapi berkaitan dengan penyakit yang dideritanya, ataupun konsultasi yang menyangkut prilaku keberagamaan. 
Komunikasi Terapeutik Perawat Rohani Islam dalam Proses Penyembuhan Pasien di RSUD Ciamis

Contoh kasus seperti yang terjadi pada pasien Tn. Muhadi (65 Tahun) dan Ny. Nengsih (44 Tahun). Pasien Tn. Muhadi oleh dokter didiagnosa CHF (Coroner Heart Failure) jantung dan Hipertensi. Penyakitnya akan kambuh ketika melihat si X atau mendengar nama X disebut. Ketika petugas Warois melakukan kegiatan visite rutin ke ruang rawat inap dan berinteraksi dengan pasien Tn. Muhadi, dan menanyakan bagaimana keadaan bapak Muhadi sekarang, dia menjawab al-Hamdulillah baik, tapi kadang - kadang secara tibatiba dada suka terasa sesak dan tensi naik apabila melihat dan mendengar nama X. Ketika ditanya oleh petugas Warois ada permasalahan apa dengan nama X tersebut danbagaimana latarbelakangnya. Maka Tn. Muhadi bercerita panjang lebar tentang nama $\mathrm{X}$ tersebut sampai Tn. Muhadi punya penyakit jantung dan hipertensi. Maka dari cerita tersebut tertangkap inti atau substansi dari permasalahan yang menyebabkan Tn. Muhadi sakit dengan diagnosa jantung CHF dan hipertensi. Ini adalah masalah mental atau psikis, penyakit non fisik (penyakit Rohani), tapi menjadi masalah fisik yaitu penyakit fisik. Tn. Muhadi merasa tidak dihargai oleh si $\mathrm{X}$,dan si $\mathrm{X}$ tersebut tidak tahu rasa terima kasih, yang akhirnya membuat Tn Muhadi sakit hati. Adapun solusi yang disarankan petugas Warois kepada Tn. Muhadi adalah menjadi seorang yang pema'af dan berjiwa lapang. Karena mema'af kan kesalahan orang lain atas dirinya dapat menjadi obat yang manjur untuk menyembuhkan sakit dirinya. Meskipun si X tidak mengetahuinya ia telah di ma'afkan, karena mungkin ia tdak merasa punya salah.

Demikian pula dengan pasien yang bernama Ny. Ningsih (44 tahun). Ia oleh dokter didiagnosa hipertensi dan asam lambung (maag), sehingga sering sakit kepala. Awal mula memiliki Hipertensi dan Maag karena disakiti oleh suaminya. Suaminya merantau dan punya istri lagi di rantau dan dia ditinggalkan begitu saja. Meskipun akhirnya dia mengakhiri hubungan suami istri dengan gugat cerai. Tapi sakit hati yang disebabkan oleh prilaku mantan suaminya itu masih berbekas dan masih menjadi pikiran, meskipun telah bercerai. Petugas Warois memberikan layanan konseling kepada pasien $\mathrm{Ny}$. Ningsih dengan cara komunikasi interpribadi. Maka resep agar Ny. Ningsi sembuh total adalah menjadi seorang pema'af. Artinya kelakuan mantan suaminya itu dima'afkan dengan sungguh-sungguh dan tulus.

Kegiatan yang dilakukan oleh petugas Perawatan Rohani Islam (Warois) pada hakekatnya, merupakan dakwah fardiyah (perseorangan) yang dilakukan secara tatap muka, yang dalam komunikasi disebut komunikasi interpersonal antara petugas Warois dengan pasien dan keluarganya, yang dilakukan secara tatap muka (face to face). Interpersonal Communication (komunikasi interpesonal), adalah salah satu dari beberapa jenis atau level komunikasi dalam ilmu komunikasi. Komunikasi interpersonal merupakan interaksi tatap muka antar dua atau tiga orang, di mana pengirim atau sumber dapat menyampaikan pesan secara langsung, dan penerima pesan dapat menerima dan menanggapinya secara 
Ibin Hasani

langsung.

Komunikasi terapeutik petugas Perawatan Rohani Islam adalah suatu kegiatan interaksi komunikasi yang dilakukan oleh petugas perawatan rohani Islam dengan pasien rawat inap dan keluarganya, dengan tujuan memberikan terapi. Kegiatan tersebut dilakukan melalui layanan bimbingan tadzkirah (nasihat), bimbingan Ibadah, do'a, dan dzikir serta konseling keagamaan. Konten pesan yang disampaikan kepada pasien rawat inap dalam komunikasi terapeutik yaitu: motivasi dan dorongan bagi pasien, dan keluarga yang menunggu. Agar mereka selalu optimis dan berbusnudhan (berbaik sangka) kepada Allah SW'T., bahwa Allah akan segera menyembuhkannya dari sakit yang dideritanya.

\section{Metode dan Teknik Komunikasi Trapeutik Perawatan Rohani Islam.}

Metode atau cara yang dilakukan oleh petugas Perawatan Rohani Islam (Warois) RSUD Ciamis dalam berinteraksi dan berkomunikasi dengan pasien rawat inap meliputi:

Survai Data dan Informasi Pasien, sebelum masuk ruang perawatan dan bertemu dengan pasien, pertugas perawatan Rohani Islam (Warois) terlebih dahulu mencari data dan informasi tentang pasien yang meliputi : Nama pasien, jenis kelamin pasien, alamat pasien, pekerjaan pasien, status keluarga pasien, dan diagnosa penyakit yang diderita pasien, riwayat penyakit pasien dan kondisi pasien-pasien yang ada di ruang perawatan. Dengan maksud untuk medapatkan gambaran awal kondisi pasien yang ada di ruang perawatan dan internalisasi atau komunikasi intrapribadi petugas perawatan rohani Islam.

Menyapa pasien diruang perawatan, petugas Perawatan Rohani Islam (warois) masuk ke ruang perawatan pasien dan menyapanya dengan mengucapkan salam dan sekaligus memperkenalkan diri (self introduction) secara umum kepada pasien dan keluarga yang ada di ruangan tersebut.

Berjabat tangan atau bersalaman, petugas Warois melakukan jabat tangan dengan pasien sambil membacakan do'a kesembuhan bagi pasien. Hal ini sangat menentukan strategi komunikasi petugas perawataan rohani Islam selanjutnya. Karena pada sesi ini sisi psikologinya telah tersentuh ketika bersalaman dan dengan dibacakan do'a kesembuhan.

Interaksi komunikasi secara perorangan (interpersonal communication), pada komunikasi interpersonal tersebut petugas perawatan rohani Islam (Warois) menggali informasi yang berkaitan dengan pengamalan dan pemahaman keberagaman pasien selama sakit dan dirawat di RSUD Ciamis. Hal tersebut sangat penting untuk memberikan terapi rohani pasien, sekaligus sebagai strategi untuk interaksi komunikasi selanjutnya. Diawal pertemuannya dengan pasien,petugas Warois sudah memberikan sentuhan pada sisi psikologi yaitu, dengan berjabat tangan atau bersalaman sambil membacakan do'a 
Komunikasi Terapeutik Perawat Rohani Islam dalam Proses Penyembuhan Pasien di RSUD Ciamis kesembuhan.Dalam interaksi komunikasi tersebut terjadi layanan yang berupa tausiah atau nasihat yang menghibur, serta pemberian semangat dan motivasi agar tetap sabar dan ikhlas dalam menerima musibah sakit tersebut, serta diberangi dengan ikhtiar dan tawakal kepada Allah SWT. dan berhusnudhan(berprasangka baik) kepada -Nya. Dengan penuh keyakinan dan optimis, bahwa: Do'a yang senantiasa dipanjatkannya serta dzikir yang dilakukannya setiap saat, akan diijabah oleh Allah SWT., serta penyakit yang dideritanya akan diangkatnya dan disembuhkan tanpa meninggalkan bekas.

Penyampaian pesan oleh perawat rohani Islam (Warois) kepada pasien selaku penerima pesan, tentunya akan berbeda dengan apa yang dilakukan oleh perawat medis.Petugas Warois ketika bertemu dengan pasien harus mengucapkan salam, yang dalam ucapan salam saja sudah mengandung do'a keselamatan, kemudian bermushafahah (bersalaman), ketika bermushafahah di bacakan lagi do'a untuk kesembuhan.

Berkomunikasi yang terapeutik pernah dicontohkan oleh Rasulullah SAW. Baik secara verbal maupun non verbal. Sebagaimana tercantum dalam sebuah hadis, yang berbunyi:

Dari Aisyah R.A bahwasanya Nabi SAW. menjenguk salah seorangkeluarganya, dengan mengusapkan tangan kanannya seraya bedo'a: Ya Allah Rab semua manusia hilangkanlah segala penyakit, sembuhkanlah, karena hanya Engkaulah yang dapat menyembuhkan, tiada kesembuhan melainkan kesembuhan dari pada- Mu, kesembuhan yang tidak dihinggapi penyakit lagi (HR. Bukhari dan Muslim).

Hadis tersebut menginformasikan, bagaimana cara Rasulullah SAW., melakukan komunikasi terapeutik, kepada orang sakit (cara mendo'akan orang sakit), sewaktu beliau menengok sahabat atau umat Islam yang terkena musibah sakit. Rasulullah melakukan komunikasi terapeutik ketika menjenguk salah satu keluargan dengan menggunakan bahasa verbal dalam bentuk ucapan do'a, dan bahasa nonverbal melalui sentuhan tangan yang diusapkan atau ditempelkan ketubuh orang yang sakit pada saat Rasulullah SAW. membacakan do'a. Dalam komunikasi bahasa nonverbal memiliki makna yang dalam dibanding dengan bahsa verbal.

Adapun teknik pelaksanaan komunikasi terapeutik oleh petugas Warois, sebagaimana yang dikemukakan Perry dan Potter (2005), yaitu meliputi: interaksi sosial, menyimak dengan penuh perhatian, menunjukan penerimaan, mengajukan pertanyaan yang berhubungan, parafrase, menjelaskan fokus, menetapkan observasi, memberikan informasi yang dibutuhkan, mempertahankan ketenangan, dan memberikan kesimpulan.

Demikian pula komunikasi terapeutik petugas perawatan rohani Islam (Warois), dalam menanggapi pesan yang disampaikan pasien atau keluarganaya, petugas Warois menggunakan berbagai teknik komunikasi terapeutik yang biasa digunakan oleh perawat medis. Adapun yang membedakannya adalah konten 
pesan yang disampaikan kepada pasien. Konten pesan yang disampaikan petugas perawatan rohani Islam adalah pesan-pesan Tauhid, Ibadah, dan akhlaq, yang bersumber dari ajaran agama Islam.

Teknik komunikasi terapeutik yang sedemikan banyak itu tidak semuanya digunakan oleh petugas Warois, hanya beberapa teknik saja yang sering digunakan oleh petugas Warois dalam melakukan komunikasi terapeutik dengan pasien, yaitu : 1) Bertanya (Questioning), bertanya (questioning) merupakan teknik yang dapat mendorong pasien untuk mengungkapkan perasaan dan pikirannya. Teknik ini sering digunakan pada tahap perkenalan atau orientasi. Teknik bertanya dapat menggali berbagai informasi yang penting tentang problem yang dihadapi oleh pasien, terutama yang berkaitan dengan penyakit yang dideritanya. Sehingga sangat memudahkan bagi petugas Warois untuk menentukan layanan yang akan dan harus diberikannya agar pasien tersebut memiliki semangat dan optimis untuk sembuh. 2) Mendengarakan dengan aktif (active listening) dan penuh kesungguhan, mendengarakan dengan aktif (active listening) dan penuh kesungguhan artinya menjadi pendengar yang baik, ini merupakan keterampilan dasar dalam melakukan interaksi antara petugas Warois dengan pasien. 3) Menunjukkan penerimaan, teknik menunjukkan penerimaan berarti petugas Warois bersedia untuk mendengarkan orang lain tanpa menunjukan keraguan atau ketidak setujuan. 4) Memberi kesempatan kepada pasien untuk memulai pembicaraan, artinya memberi kesempatan kepada pasien untuk mengambil inisiatif dalam memilih topik pembicaraan. 5) Memberikan penghargaan, hal ini dapat dilakukan dengan cara menyambut pasien dengan salam dan menyebut namanya serta dengan berjabat tangan. 6) Mengulang ucapan pasin dengan menggunakan kata - kata sendiri, teknik mengulang ucapan pasien dengan kata - katasendiri tujuannya untuk menyatakan kepada pasien bahwa petugas Warois sudah paham dan mengerti terhadap pesan yang disampaikan, dan mengharapkan komunikasi berlanjut. 7) Klarifikasi, teknik klarifikasi tujuanya untuk meluruskan jika terjadi kesalah pahaman, maka petugas Warois senantiasa memberikan klarifikasi untuk menyamakan pemahaman dan persepsi. 8) Memfokuskan, teknik ini dilakukan dengan tujuan membatasi pembicaraan, sehingga lebih spesifik dan dimengerti. Komunikasi yang dilakukan petugas Warois terfokus terhadap tema atau masalah inti yang dihadapi oleh pasien. 9) Menyampaikan hasil observasi, petugas Warois perlu memberikan respon kepada pasien dengan menyatakan hasil pengamatannya, sehingga dapat diketahui apakah pesan diterima dengan baik dan benar.Petugas Warois menguraikan kesan yang ditimbulkan melalui isyarat non-verbal pasien.Penyampaian hasil pengamatan petugas Warois dapat membuat pasien berkomunikasi lebih jelas tanpa harus memfokuskan atau mengklarifikasi pasien. 10) Diam (Silence), teknik diam ini tujuannya untuk memberikan kesempatan kepada petugas Warois dan pasien untuk mengorganisasikan pikiran masing - 
Komunikasi Terapeutik Perawat Rohani Islam dalam Proses Penyembuhan Pasien di RSUD Ciamis masing (Suryani, 2017: 64). Diam memungkinkan pasien untuk berkomunikasi dengan dirinya sendiri dalam merespon informasi yang ada. Penggunaan teknik silence yang tepat dapat menurunkan ketegangan pasien dalam mengungkapkan suatu pengalaman yang traumatis bagi diriya. Penggunaan teknik diam memerlukan keterampilan dan ketepatan waktu, karena jika tidak demikian akan menimbulkan perasaan tidak enak. 11) Meringkas, meringkas adalah mengulang ide utama yang telah dikomunikasikan secara singkat.Teknik ini bermanfaat untuk membantu topik yang telah dibahas sebelum meneruskan pada pembicaraan berikutnya. Teknik ini membantu petugas Warois mengulang aspek penting dalam interaksinya, sehingga dapat melanjutkan pembicaraan dengan topik lain yang berkaitan. 12 ) Humor, teknik humor memiliki beberpa fungsi dalam hubungan terapeutik petugas Warois dan pasien. Menurut Antai -Otong (2008), suatu pengalaman pahit sangat baik ditangani dengan humor, karena humor dapat menyediakan tempat bagi emosi untuk distraksi dari perasaan stress dan depresi (Suryani, 2017 : 69). Dengan melakukan humor otot - otot yang tadinya tegang menjadi kendur, perasaan yang kacau akan menjadi terhibur sehingga muncul kesiapan untuk memecahkan masalah yang sedang dihadpai. Humor menurut Dugan (1989) adalah suatu hal yang penting dalam komunikasi verbal, karena tertawa dapat mengurangi ketegangan dan rasa sakit akibat stress. Contoh teknik humor dalam komunikasi terapeutik petugas Warois, " Shalat merupakan ibadah badaniyah yang fardlu bagi setiap individu muslim yang sudah balig, ibadah tersebut tidak bisa tergantikan oleh apapun. Sebagaimana keterangan yang tertera dalam hadis nabiSAW., yang berbunyi:

"Shalatlah kamu dengan berdiri, apabila tidak mampu dengan berdiri maka shalatlah kamu dengan duduk, apabila tidak mampu dengan duduk, maka shalatlah kamu dengan berbaring ( kepala berada disebelah kanan dengan menghadap kiblat), maka apabila tidak mampu dengan berbaring, maka berisyaratlah",pada hadis lain berbunyi : "Jadikanlah sujudmu lebih rendah dari ruku".

Dan secara berkelakar atau humor petugas Warois menambahkan, maka apabila dengn isyarat sudah tidak mampu, maka shalatkanlah orang Islam itu oleh banyak orang, berarti kondisinya kalau demikian sudah lain yaitu sudah jadi mayat. Saking pentingnya ibadah shalat dalam agama Islam, maka setelah meninggalpun karena tidak bisa shalat sendiri, dan sudah menjadi jenazah, maka harus dishalatkan oleh orang Islam yang masih hidup, dan apabila tidak ada yang menshalatkan maka hukumnya dosa bagi seluruh umat Islam yang ada dilingkungan tersebut. Karena hukum shalat jenazah itu adalah fardlu, tapi fardlu kifayah, artinya kalau ada sebagian orang yang telah melaksanakannya maka gugurlah kewajian tersebut bagi yang lainnya. Contoh lain humor positif dan mendidik dalam komunikasi terapeutik petugas Warois adalah dalam berdo'a. ' Bapak/ Ibu berdo'a itu adalah memohon atau meminta kepada Allah SWT., Dalam hidup ini kita jangan suka kas bon terus, sehingga saking seringnya kas 
bon perusahan rugi, karena upah telah dikeluarkan lebih dahulu sementara kerjanya belum dilaksanakn, demikain dalam berdoa'a kepada Allah, memohon atau berdo'a terus takhenti- henti sementara kewajiban beramal ibadah terlewatkan dan banyak bolong - bolongnya. Berdo'a dan amal ibadah harus berimbang sehingga akan cepat ijabahnya do'a kita, sebagaimana firman Allah SWT ; dalam Q.S. Al-Baqarah : 186).

Dan apabila hamba-hamba-Ku bertanya kepadamu tentang Aku, maka (jawablah), bahwasanya Aku adalah dekat. Aku mengabulkan permohonan orang yang berdoa apabila ia memohon kepada-Ku, maka hendaklah mereka itu memenuhi (segala perintah-Ku) dan hendaklah mereka beriman kepada- $\mathrm{Ku}$, agar mereka selalu berada dalam kebenaran.

Allah SWT., sangat paham akan sifat dan watak manusia, apabila manusia itu sudah selesai bekerja maka akan minta upah, maka firman Allah SWT., dalam Q. S. At- Tiin: 6)

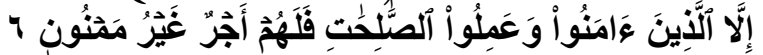

Kecuali orang-orang yang beriman dan mengerjakan amal saleh; maka bagi mereka pahala yang tiada putus-putusnya.

\section{Pesan Komunikasi Terapeutik Perawatan Rohani Islam.}

Pesan komunkasi terapeutik petugas Perawatan Rohani Islam (Warois) artinya konten pesan yang disampaikan petugas perawatan rohani Islam (Warois)memiliki khasiat terapi, bagi pasien. Karena tujuan dari komunikasi terapeutik petugas Warois itu adalahuntuk memberikan efek terapi (kesembuhan).

Komunikasi terapeutik yang dijalin petugas Warois dengan pasien rawat inap tersebut harus mampu memberikaan efek terapi bagi pasien yang dikunjunginya, maka diperlukan suatu strategi penyusunan pesan, agar pesan yang disampaikan petugas Warois itu berkhasiat terapi..

Dampak dari komunikasi tersebut adalah terjadinya perubahan kearah yang lebih baik, apakah itu prilaku atau persepsi dalam diri pasien, dan itu sebagai respon atau efek dari komunikasi terapeutik yang dilakukan oleh petugas perawatan rohani Islam (Warois).

Pesan yang disampaikan petugas perawatan rohani Islam (Warois) kepada pasien rawat inap adalah berupa nasihat spiritual (tadzkirah), yaitu menjelaskan harus bagaimana akhlak seorang muslim ketika menderita sakit, dan prilaku yang ditampilkannya harus seperti apa? karena akhlaq atau berprilaku yang baik akan berpengaruh positif, sehingga akan mempercepat proses kesembuhan, bimbingan ibadah, bimbingan do'a dan dzikir serta konseling. Pesan - pesan tersebut semuanya bersumber dari ajaran agama Islam, yakni yang terdapat dalam al-Qur'an dan al-Sunnah Rasulullah SAW. Konten pesan tersebut yang membedakan antara komunikasi terapeutik yang dilakukan oleh petugas perawat 
Perawatan Rohani Islam (Warois) dengan perawat medis dan petugas kesehatan lainnya.

Pengetahuan petugas Warois terhadap kondisi sosial, ekonomi serta pendidikan pasien adalah suatu hal yang sangat penting dalam komunikasi terapeutik Warois. Karena berkaitan dengan bahasa yang digunakan dalam menyampaikan pesan, sehingga komunikasinya menjadi efektif. Kitab suci AlQur'an, mengisyaratkan mengenai prinsip-prinsip komunikasi yang efektif dengan istilah qaulan baligha. Seperti dijelaskan dalam Al-Qur'an, surat Ibrahim ayat 14: 4, yang berbunyi:

Kami tidak mengutus seorang rasulpun, melainkan dengan bahasa kaumnya, supaya ia dapat memberi penjelasan dengan terang kepada mereka. Maka Allah menyesatkan siapa yang Dia kehendaki, dan memberi petunjuk kepada siapa yang Dia kehendaki. Dan Dialah Tuhan Yang Maha Kuasa lagi Maha Bijaksana. (Q.S.14 :4)

Ayat tersebut di atas menjelaskan bahwa seorang komunikator sebagai sumber pesan harus memilki pengetahuan tentang kondisi khalayak yang menjadi penerima pesan (audien). Agar pesan yang disampaikannya menjadi efektif dan menyentuh psikologi audien.

Pesan komunikasi terapeutik petugas Warois yang berbentuk, bimbingan akhlaq atau nasihat (tadzkirah), bimbingan ibadah mabdhoh (shalat fardlu yang lima waktu), bimbingan dzikir dan do'a serta konseling, keseluruhannya disampaikan kepada pasien rawat inap RSUDCiamis, dan keluarga yang menunggunya. Cara penyampaiannya, tiap jenis konten pesan tersebut tidak sama, disesuaikan dengan situasi dan kondisi pasien serta keluaraga, pada saat itu. Karena situasi dan kondisi pasien serta keluarga sangat menetukan akan keberhasilan (efektifitas) komunikasi.

Aktifitas penyampaian pesan terapeutik petugas Warois kepada pasien rawat inap RSUD Ciamis dilakukan dalam pada beberapa kegiatan, yaitu :

$V$ isite (kunjungan) ke pasien rawat inap dibagi kepada empat kategori, yaitu : Visite ke ruang perawatan secara rutin sesuai dengan SPO. Visite ke ruang perawatan karena ada permintaan dari perawat jaga ruangan. $V$ isite ke ruang perawatan karena ada permintaan dari pasien itu sendiri

Penyampain pesan melalui audio, penyampaian pesan melaui audio dilakukan setiap waktu shalat tiba, yaitu setelah selesai dikumandangkannya adzan.

Penyampaian pesan yang dianggap lebih tepat dan efektif adalah dengan teknik humor. Teknik humor yaitu, satu teknik komunikasi terapeutik yang diselingi dengan humor yang mendidik (educatied), sehingga tanpa disadari oleh pasien nasihat yang dikemas dengan kelakar dan humor oleh petugas Warois itu mengena terhadap psikologinya, maka dengan tanpa merasa tersinggung, pasien dapat menerima dan memahami pesan - pesan yang disampaokan petugas Warois dan mau mengerjakan kewajiban keragamaan dengan tulus dan ikhlas.

Layanan perawatan rohani Islam selain sebagai layanan kesehatan juga merupakan bagian dari kegiatan dakwah, maka prinsip-prinsip komunikasi atau penyampaian pesan yang efektif (qawlan baligha) harus diterapkan, agar pesan 
atau konten dakwah yang disampaikan bisa diterima dengan baik, yakni berefek positif bagi kehidupan masyarakat. Di antara prinsip-prinsip komunikasi (qawlan baligha) sebagaimana yang dikemukakan oleh Jalaluddin Rakhmat, yaitu :1)Qawlan baligha terjadi apabila komunikator menyesuaikan pembicaraannya dengan sifat sifat khalayak yang dihadapinya. Dalam istilah Al-Qur'an, ia berbicara " $f i$ anfusibim" (tentang diri mereka). Dalam istilah Sunnah " berkomunikasilah kamu sesuai dengan kadar akal mereka”. Pada zaman modern, ahli komunikasi berbicara tentang frame of reference dan field of exprerience. Komunikator baru efektif, bila ia menyesuaikan pesannya dengan kerangka rujukan dan medan pengalaman khalayaknya. Sebagaimana dijelaskan dalam Al-Qur'an (Q.S. Ibrabim :4). 2) Qawlan baligha terjadi bila komunikator menyentuh khalayaknya pada hati dan otaknya sekaligus. Istilah Aristoteles menyebut ada tiga cara persuasi mempengaruhi manusia yang efektif : ethos, logos dan pathos. Dengan ethos sebetulnya merujuk kepada kualitas komunikator. Komunikator yang jujur, dapat dipercaya, memiliki pengetahuan yang tinggi, akan sangat efektif untuk mempengaruhi khalayaknya. Dengan logos, kita meyakinkan orang lain tentang kebenaran argumentasi kita. Kita mengajak mereka berpikir, menggunakan akal sehat, dan membimbing sikap kritis. Kita tunjukan bahwa kita benar, karena secara rasional argumentasi kita harus diterima. Dengan pathos kita a "bujuk" khalayak untuk mengikuti pendapat kita, kita getarkan emosi mereka, kita sentuh keinginan mereka dan kerinduan mereka, kita redakan kegelisahan dan kecemasan mereka (Rakhmat, 2004:85).

\section{Keberhasilan Komunikasi Terapeutik dalam Membantu Proses Penyembuhan Pasien}

Keberhasilan komunikasi terapeutik yang dilakukan oleh petugas Perawatan Rohani Islam (Warois) RSUD Ciamis tidak lepas dari dukungan Pemerintah Daerah Kabupen Ciamis, yang dalam hal ini dengan dikeluarkannya regulasi kebijakan Bupati Ciamis yang tertuang pada : 1). Surat Keputusan Bupati Ciamis Nomor : 445/Kpts.243/RSUD/VI/2016. Tentang Hak Pasien Dan Keluarga Pada Rumah Sakit Umum Daerah Ciamis.Tertanggal 01 november 2016. “ Bahwa pasien berhak menerima dan menolak pelayanan bimingan rohani yang tidak sesuai dengan agama dan kepercayaan yang dianutnya.”. Selanjutnya “ Pasien berhak menjalankan ibadah sesuai agama / kepercayaan yang dianutnya selama tidak mengganggu pasien lainya. 2). Surat Keputusan Bupati Ciamis Nomor : 445/Kpts. 224/RSUD/XI/2016, “ Tentang Pemberlakuan Panduan Pelayanan Kerohanian pada Rumah Sakit Umum Daerah Ciamis “. Dalam lampiran Surat Keputusan Bupati Ciamis Nomor : 445/Kpts. 224/RSUD/XI/2016, Tentang Pemberlakuan Panduan Pelayanan Kerohanian pada Rumah Sakit Umum Daerah Ciamis. Antara lain brisi: a). Bahwa Pelayanan Kerohanian diberikan 24 jam di seluruh unit pelayanan, untuk 
Komunikasi Terapeutik Perawat Rohani Islam dalam Proses Penyembuhan Pasien di RSUD Ciamis memenuhi kebutuhan spiritual menurut agama dan kepercayaannya dalam rangka memberikan pelayanan yang holistik kepada pasien tanpa paksaan/atas izin pasien/keluarga sesuai kebutuhan pasien / terjadwal rutin oleh Warois Rumah Sakit Umum Daerah Ciamis.

b). Pelayanan kerohanian yang diberikan tidak akan menganggu pasien lain, apabila pelayanan dirasakan mengganggu/ jika pasien daan keluarga menolak, maka petugasWarois berhak menghentikan pelayanan tersebut. c). Rumah Sakit akan memfasilitasi kebutuhan rohaniawan menurut agama dan kepercayaan pasien dari luar rumah sakit untuk mendapatkan bimbingan pelayanan kerohanian. d). Apabila ada kebutuhan pelayanan kerohanian yang bersifat tidak rutin, pasien/ keluarga bisa menghubungi petugas ruangan untuk selanjutnya disampaikan kepada Warois Rumah Sakit.

Selain tersebut diatas, keberhasilan komunikasi terapeutik petugas Warois didukung oleh adanya perencanaan, strategi yang dibuat oleh Lembaga Perawatan Rohani Islam (Warois) RSUD Ciamis, dan kerjasama yang sinergis antara petugas Warois dengan dokter, perawat medis dan elemen lainnya yang terlibat dalam perawatan pasien, sehingga terjadi integrasi dalam perawatan yang saling mendukung.

Keberhasilan komunikasi terapeutik petugas perawatan rohani Islam dapat dilihat dari adanya respon yang positif dari pasien dan keluarga, yaitu adanya perubahan prilaku pada diri pasien dan keluarga. Selain itu keberhasilan komunikasi terapeutik petugas perawatan rohani Islam dapat dilihat dari respon pasien, yaitu adanya perubahan prilaku pada diri pasien, seperti tertera pada tabel berikut :

\section{Tabel Perubahan Prilaku Pasien}

\begin{tabular}{|c|c|c|}
\hline \multirow{2}{*}{$\begin{array}{l}\text { Keadaan } \\
\text { (Kondisi) } \\
\text { Pasien }\end{array}$} & \multicolumn{2}{|c|}{ Prilaku Pasien } \\
\hline & $\begin{array}{c}\text { Sebelum dilakukan } \\
\text { Bimbingan Konseling } \\
\text { (komunikasi Terapeutik) oleh } \\
\text { Petugas Warois }\end{array}$ & $\begin{array}{c}\text { Sesudah dilakukan } \\
\text { Bimbingan Konseling } \\
\text { (komunikasi Terapeutik) } \\
\text { oleh Petugas Warois }\end{array}$ \\
\hline Prilaku / Akhlaq & $\begin{array}{c}\text { Berteriak- teriak, Marah - } \\
\text { Marah, Histeria }\end{array}$ & $\begin{array}{l}\text { Dzikir dan beristigfar, } \\
\text { Ramah dan Santun }\end{array}$ \\
\hline Kondisi Fisik & $\begin{array}{c}\text { Gelisah, Tidak bisa Tidur, } \\
\text { Tensi - Tinggi }\end{array}$ & $\begin{array}{c}\text { Tenang, Bisa Tidur, Tensi } \\
\text { Normal }\end{array}$ \\
\hline $\begin{array}{l}\text { Pengamalan / } \\
\text { Prilaku } \\
\text { keberagamanan }\end{array}$ & $\begin{array}{l}\text { Tidak mau, Melaksanakan } \\
\text { shalat fardlu, berdo'a, dan } \\
\text { berdzikir }\end{array}$ & $\begin{array}{c}\text { Mau elaksanakan shalat } \\
\text { Fardu, mau berdoa dan } \\
\text { berdzijir dengan } \\
\text { kesadarannva sendiri }\end{array}$ \\
\hline
\end{tabular}

Pada hakekatnya sehat dan sakit itu urusan dan ketetapan Allah SWT., sebagaimana firma-Nya (Q.S Al-Syu'aro : 80) yang berbunyi : 
Ibin Hasani

وَإِذَا مَرِضْتُ فَهُوَ بَثَثْفِينِ

"Dan apabila aku sakit. Dialah yang menyembubkan aku".

Secara keseluruhan hasil temuan penelitian komunikasi terapeutik petugas perawatan rohani Islam (Warois) dalam membantu proses penyembuhan pasien rawat inap RSUD Ciamis, meliputi : (1) Proses Komunikasisi terapeutik yang dilakukan petugas perawatan rohani Islam dalam mengintervensi pasien. (2) Metode dan teknik komunikasi terapeutik petugas Warois. (3) Pesan Komunikasi terapeutik petugas Warois. (4) Hasil komunikasi terapeutik petugas Warois dalam membantu proses penyembuhan pasien rawat inap di RSUD Ciamis.

Proses Komunikiasi terapeutik petugas Perawatan Rohani Islam (Warois), dalam mengitervensi pasien rawat inap RSUD Ciamis, mengacu pada Standar Operasional Prosedur (SOP) petugas perawatan rohani Islam dalam visite atau kunjungan ke pasien rawat Inap RSUD Ciamis, dengan Nomor 01/Warois/ $\mathrm{XI} / 2016$.

Standar Prosedur Oprasi Kunjungan / Visite petugas Warois ke ruang perawatan pasien: 1). Datang ke ruangan petugas jaga dengan mengucapkan salam. 2). Menanyakan status/keadaan pasien kepada perawat jaga.3). Masuk ke ruang perawatan dengan membaca salam dan do'a menjenguk pasien. 4). Menyapa pasien dan mengenalkan identitas diri sebagai pelaksana kerohanian kepada pasien dan keluarga yang menunggu. 5). Meminta ijin untuk menemui pasien kepada keluarganya, apabila tidak ditemani keluarganya, maka ijin ditujukan kepada pasien. 6). Menanyakan kondisi pasien, dan apa yang dirasakan oleh pasien, dengan menyentuh tubuh pasien bila muhrim. 7). Menanyakan pelaksanaan pengamalan kewajiban keberagamaan pasien selama dirawat di RSUD Ciamis. 8). Melakuan bimbingan, yang meliputi:tadqkirah, ibadah, do'a, dzikir dan konseling) sesuai dengan kondisi pasien sa'at itu. 9). Mendo'akan pasien supaya lekas sembuh.10). Pelaksanaan kerohanian menuliskan kunjungan pelayanan kerohanian. 11). Setelah selesai, minta ijin untuk meninggalkan ruangan dengan mengucapkan salam pada pasien dan keluarganya.

Meskipun petugas Perawatan Rohani Islam (Warois) tidak mengenal atau mengetahui tentang komunikaasi terapeutik, tapi dalam panduan standar oprasional prosedur yang dibuatnya dalam berkunjung ke ruang perawatan untuk melakukan bimbingan rohani (tadzkirah, bimbinga ibadag, do'a, dzikir dan konseling) sama dengan tahapan dan strategi komunikasi terapeutik.

Demikian juga pada metode dan teknik bimbingan yang dilakukan oleh petugas perawatan rohani Islam (Warois), bisa dikatakan sama dengan metode dan teknik komunikasi terapeutik pada umumnya. Di RSUD Ciamis, kegiatan petugas Warois dalam memberikan layanan kepada pasien rawat inap, pertama Dilihat dari sudut pandang komuikasi termasuk pada jenis komunikasi terapeutik, yaitu komunikasi yang secara khusus pada awalnya hanya digunakan 
Komunikasi Terapeutik Perawat Rohani Islam dalam Proses Penyembuhan Pasien di RSUD Ciamis

oleh petugas kesehatan (perawat, bidan, psikiater dan dokter) dalam berkomunikasi dengan kliennya, untuk tujuan penyembuhan. Komunikasi terapeutik seperti telah disebutkan terdahulu merupakan critical skill perawat atau petugas kesehatan lainnya. Hal ini di RSUD Ciamis dilakukan petugas Warois, karena secara khusus perawat medis tidak dapat melakukan komunikasi terapeutik, dengan alasan terbatasnya sumberdaya manusia yang ada. Kedua dilihat dari prespektif ilmu dakwah termasuk pada jenis dakwah Nafsiah (dakwah terhadap diri sendiri seperti ketika sedang internalisasi atau komunikasi intrapribadi), fardiyah (dakwah terhadap perorangan yang dilakukan dengan cara tatap muka (pace to face) atau komunkasi interpribadi) dan fi'ah qalilah (dakwah terhadap kelompok kecil yang terdiri dari 3 - 5 orang)..

Pesan yang disampaikan petugas Warois adalah pesan keagamaan yang bersumber dari Al-Qur'an dan As-Sunnah, artinya pesan yang disampaikan petugas Warois kepada pasien rawat inap tidak lain adalah nasihat - nasihat agama atau spiritual yang bersumber dari ajaran agama. Bagaimana pesan pesan agama bagi orang yang sedang sakit itu mampu menjadi terapi. Dalam agama Islam, sehat dan sakit itu sebenarnya adalah ujian keimanan kepada Allah. Petugas perawatan rohani Islam (Warois) senantiasa menyampaikan pesan dalam berkomunikasi dengan pasien dan keluarga itu berupa dorongan dan motivasi, agar pasien dan keluarga selalu optimis dengan terus menerus berdo'a kepada Allah agar diberi kekuatan, kesabaran dan keiklasan serta cepat disembuhkan kembali dengan diangkat penyakit tersebut dari diri pasien tersebut. Pesan yang disampaikan petugas Warois, menjadi pembeda antara komunikasi terapeutik petugas perawatan rohani Islam dengan perawat medis.

\section{PENUTUP}

Proses komunikasi terapeutik petugas perawat rohani Islam (Warois) dilakukan melalui empat tahap yaitu; a) tahap persiapan (prainteraksi), b) tahap perkenalan (orientasi), c) tahap kerja (tahap inti dari seluruh proses komunikasi terapeutik, d) tahap akhir (terminasi). Selanjutnya peroses komunikasih merupakan serangkaian peristiwa interaksi penyampaian pesan dari petugas Warois sebagai komunikator kepada pasien rawat inap sebagai komunikan (penerima pesan), sehingga dapat menciptakan suatu persamaan makna antara komunikan dengan komunikatornya. Proses komunikasi terapeutik petugas Warois bertujuan untuk menciptakan komunikasi yang memiliki pengaruh kesembuhan (terapi) bagi pasien rawat inap, sehingga komunikasi tersebut harus mampu memberikan efek kesembuhan. Proses komunikasi yang dilakukan oleh petugas Warois memiliki pengaruh psikologis, kerena dapat myentuh perasaan atau emosi pasien, sehingga menjadi spirit atau motivasi dan dorongan semangat untuk sembuh, maka komunikasi tersebut dapat menjadi terapi. Karena tujuan utama dari interaksi komunikasi petugas Warois dengan pasien rawat inap dan 
keluaraga penunggunya adalah untuk memberikan pengaruh positif (positive effect) terapi dalam proses penyembuhan.

Metode dan Teknik Komunikasi Terapeutik yang dipergunakan petugas perawatan rohani Islam (Warois) dalam memberikan layanan meliputi : 1) Bertanya (Quistioning), 2) Mendengarkan (Active Listening), 3) Menunjukan penerimaan, memberi kesempatan kepada pasien untuk memulai pembicaraan, 4) Memberikan penghargaan, 5) Mengulang ucapan pasin dengan menggunakan kata - kata sendiri, 6) Klarifikasi, 7) Memfokuskan, 8) Menyampaikan hasil observasi, 9) Diam (Silence), 10) Meringkas, 11) Menwarkan diri, 12) Humor.

Pesan yang disampaikan petugas perawatan rohani Islam (Warois) kepada pasien rawat inap adalah berupa nasihat spiritual, yaitu seperti menjelaskan akhlak seorang muslim ketika menderita sakit, dan prilaku yang harus ditampilkannya, karena akhlaq atau prilaku yang baik akan berpengaruh positif, sehingga akan mempercepat proses kesembuhan, bimbingan ibadah, bimbingan do'a dan dzikir serta konseling. Pesan - pesan tersebut semuanya bersumber dari ajaran agama Islam, yakni yang terdapat dalam al-Qur'an dan al-Sunnah Rasulullah SAW. Konten pesan tersebut yang membedakan antara komunikasi terapeutik yang dilakukan oleh petugas perawat Perawatan Rohani Islam (Warois) dengan perawat medis dan petugas kesehatan lainnya.

Keberhasilan komunikasi terapeutik petugas perawatan rohani Islam dapat dilihat dari adanya respon yang positif dari pasien dan keluarga, yaitu ada dan terjadinya perubahan prilaku pada diri pasien dan keluarga. Seperti, ketika pasien tersebut belum dilakukan bimbingan konseling oleh petugas Warois, pasien tersebut karena merasa kesakitan yang amat sangat, sehingga berteriak-teriak sangat kerat, setalh dilakukan bimbingan konseling, maka ia tidak berteiak-teriak lagi walaupun mengalami rasa sakit yang sangat, tapi ia malah bertasbih dan beristigfafar, kepada Allah SWT.

Komunikasi yang dilakukan oleh petugas Perawatan Rohani Islam (Warois) di RSUD Ciamis termasuk dalam katagori Komunikasi terapeutik, karena mengacu pada definisi yang dikemukakan para ahli bahwa komunikasi terapeutik itu adalah komunikasi yang yang dilakukan secara sadar dan terencana dengn tujuan untuk terapi.

\section{DAFTAR PUSTAKA}

Agustin, I.M. (2009). Hubungan Pelaksanan Komunikasi Terapeutik Dengan Tingkat Kecemasan Pasien Rawat Inap di BP RSUD Kebumen. Jurnal Ilmiah Kesehatan Keperawatan, 5(3).

Akhmawardani, L. (2013). Hubungan Komunikasi Terapeutik Perawat dengan Tingkat Kepuasan Pasien di Ruang Rawat Inap RSI NU Demak. Jurnal Karya Ilmiah S1 Keperawatan, 1(1).

Arifin, I. Z. ( 2015). Bimbingan dan Perawatan Rohani Islam di Rumah Sakit. 
Bandung : Mimbar Pustaka.

Azizah, S., dkk (2013). Pengaruh Komunikasi Terapeutik Terhadap Kecemasan Lansia Yang Tinggal Di Balai Rehabilitasi Sosial "Mandiri” Pucang Gading

Semarang. Jurnal Keperawatan Jiwa, 1(1).

Cangara, H. (2006). Pengantar Ilmu Komunikasi. Jakarta : Raja Grafindo Persada.

Daradjat, Z. (2002). Psikoterapi Islam. Jakarta : Bulan Bintang.

Daradjat, M.A., \& Amrullah, A.E. (2017). Pengaruh Komunikasi Terapeutik

Perawat Terhadap Kepuasan Pasien Di Ruang Rawat Inap Puskesmas

Sumbersari. Jornal Kesehatan, 5(2).

Kasron., Andhika, R., \& Kusnaeni, A. (2013). Kepuasan Pasien Jamkesmas terhadap Komunikasi Terapeutik Perawat dalam Pelayanan Asuhan Keperawatan di Ruang Kenanga RSUD Cilacap. Prosiding Seminar Nasional PPNI Jawa Tengah, 105-108.

Khotimah, N., Marsito, \& Iswati, N. (2012). Hubungan Komunikasi Terapeutik Perawat dengan Kepuasan Pelayanan Keperawatan di Ruang Inayah

Rumah Sakit PKU Muhammdiyah Gombong. Jurnal Ilmiah Kesehatan Keperawatan, 8(2), 73-80.

Littlejohn, Stephen. W dan Karen A. Foss. ( 2014). Teori Komunikasi. Jakarta : Salemba Humanika.

Mulyani, S., Paramastri, I., \& Priyanto, M.A. (2008). Komunikasi dan Hubungan

Terapeutik Perawat-Klien terhadap Kecemasan Prabedah Mayor. Jurnal Berita Kedokteran Masyarakat, 24(3).

Murwani, A. (2008). Pengantar Konsep Dasar Keperawatan. Yogyakarta : Fitramaya.

Nugroho, A., \& Aryanti, S. (2009). Hubungan antara komunikasi terapeutik

perawat dengan kepuasan pasien di Rumah Sakit Islam Kendal. Jurnal

Keperawatan, Kesehatan dan Kebidanan, 2(2), 36-41.

Pemprop Jabar. (2002). Panduan Pelaksanaan Perawatan Rohani Islam. Bandung : Pemprop Jawa Barat.

Poerwadarminta, W.J.S. ( 2014). Kamus Umum Bahasa Indonesia, Jakarta : Balai Pustaka.

Qudzail, A.M. (1987). Al-Tadawa bi al-Qur'an. Kairo: Maktabah al Turats alIslamy.

Rahayu, I. (2013). Tingkat Kepuasan Klien Akan Pola Komunikasi Terapeutik Oleh Perawat Di Rumah Sakit Bhayangkara Polda Kalbar. Jurnal ProNers, 1(1).

Rakhmat, J. (2004). Islam Aktual Refleksi Sosial seorang Cendikiawan Muslim. Bandung : Mizan

Rakhmat, J. (2014). Metode Penelitian Komunikasi. Bandung : Remaja Rosda Karya.

Rorie, P.A.C., Pondaag, L., \& Hamel, R. (2014). Hubungan Komunikasi Terapeutik Perawat Dengan Kepuasan Pasien Di Ruang Rawat Inap Irina A Rsup Prof. Dr. R. D. Kandou Manado. Jurnal Keperawatan, 2(2).

Sambas, S., \& Sukayat, T. (2002). Efistimologi Du'a. Bandung : TPK Warois 
Ibin Hasani

Pemda Jabar

Shintana, D., \& Siregar, C.T. (2012). Pengetahuan Perawat tentang Komunikasi Terapeutik dengan Perilaku Perawat. Jurnal Keperawatan Klinis, 3(1), 1-16.

Sinaulan, J.H. (2012). Komunikasi Terapeutik dalam Perspektif Islam. Jurnal Komunikasi dan Penyiaran Islam, 2(2).

Sudiansyah, A. (2018). Strategi Komunikasi untuk Meningkatkan Kesadaran Masyarakat dalam Membayar Zakat Maal. Jurnal Communicatus: Jurnal Ilmu Komunikasi, 2(1), 35-54.

Suryani. (2017). Komunikasi Terapeutik Teori dan Praktek, Ed. 2. Jakarta : EGC. Taviyanda, D. (2010). Perbedaan Persepsi Pasien terhadap Komunikasi Terapeutik antara Perawat Pegawai Tetap dengan Perawat Pegawai Kontrak di Ruang Dewasa Kelas III RS. Baptis Kediri. Jurnal Penelitian Stikes Kediri, 3(2), 72-77.

Yolanda, W.T. (2014). Rehabilitasi di Pusat Perawatan Pecandu Narkoba Ditinjau dari Komunikasi Terapeutik. Jurnal Komunikasi, 5(1). 